\title{
THE ROLE OF VOLUNTEERS IN REDUCING THE (COVID-19) SOCIAL AND ECONOMIC IMPACTS ON SOCIETY: VOLUNTARY ASSOCIATIONS AND TEAMS PERSPECTIVES IN THE SULTANATE OF OMAN"

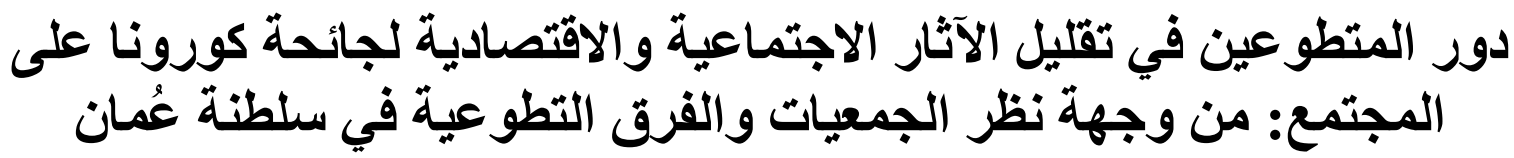

Abdullah Hammad Humaid AIMujaini*, Ministry of Education: abdullah.h.almujaini@moe.om

Faiza Ahmed Hussain AlMoosawi, Swansea University: fifi.note@gmail.com

Salma Nabhan Saif Alsalti, Caledonian College: salmaalsalti28@gmail.com

Asila Ali Hassan Almamari, Sultan Qaboos University: asila94ali1994@gmail.com

Kawthar Mohammed Shamis Al Mufarji Higher College of Technology: K.Bianca1111@gmail.com

Tamadhir Sultan Khamis AINaabi, National University: tamadhirsound@gmail.com

Ruqaia Sarhan Rashid AIMughair, Higher Institute of Health Specialists: alaman600@gmail.com

Soumar Najib Noufal, EIU France: soumarnajib@gmail.com

Wedad Khalfan Ali Alhinai,University of Technology: wedad919919@gmail.com

$$
\begin{gathered}
\text { الثبكة العمانية للمنطوعين (تعاون) } \\
\text { info@taawon.net } \\
{ }^{*} \text { Corresponding author }
\end{gathered}
$$

\begin{abstract}
The study aimed to know the real role that volunteers in voluntary associations and teams play in the Sultanate of Oman to reduce the economic and social impacts of the crises in general and the crisis of the spread of Coronavirus (Covid-19) in particular, in addition to analyzing the strengths and weaknesses of these associations and teams. The researchers depended on the survey method of voluntary associations and teams through their various websites, accounts on social media applications, and interviews. The study concluded the great role that voluntary associations and teams played in reducing the social and economic impacts of the crisis on society, the strengths and weaknesses of these voluntary associations and teams, their response to the crisis and adaptation to it, and the importance of cooperation with various institutions from the government or private sector or various civil society institutions. The study recommended the importance of training voluntary associations and teams on crisis management and supporting them financially, morally, and logistically and following up on their real role in the society.
\end{abstract}

Keywords: Crisis, Voluntary Work, (COVID-19). 


\section{الملخص}

هدفت الدر اسة إلى معرفة الدور الحقيقي الذي يقوم به المتطوعون في الجمعيات و الفرق التطوعية في سلطنة

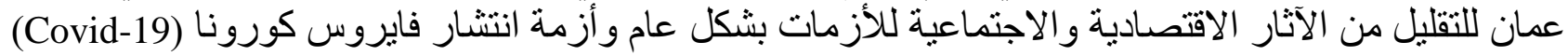

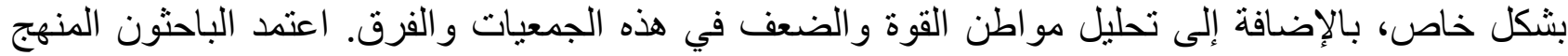

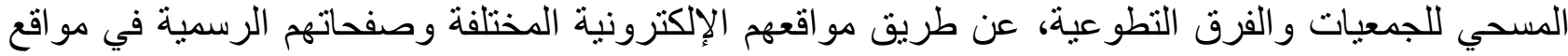

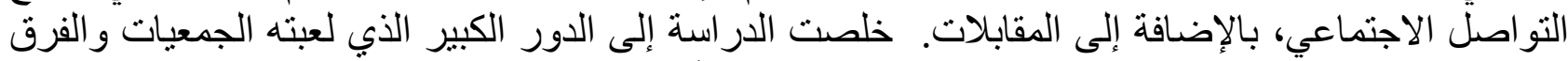

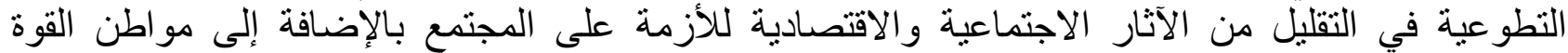

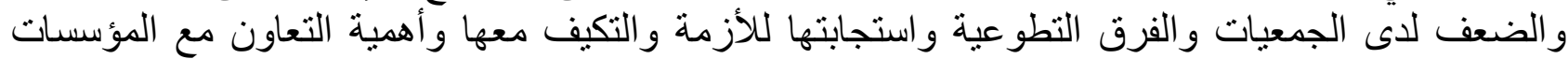

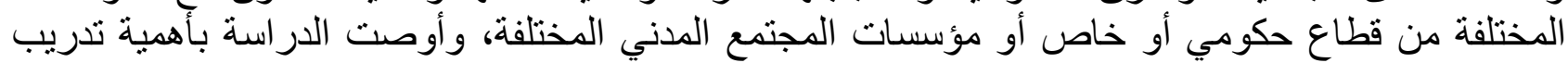
الجمعيات و الفرق التطوعية على إدارة الأزمات ودعمها ماديا ومعنويا ولوجستيا ومتابعة دور ها الحقيقي في واهي

المجتمع.

الكلمات المفتاحية: الأزمة، العمل التطوعي، جائحة كورونا.

المقدمة:

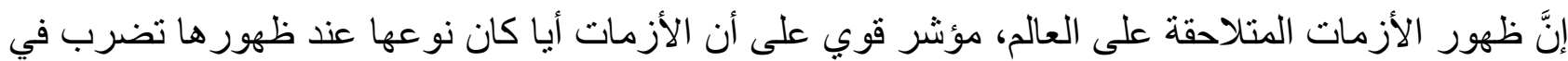

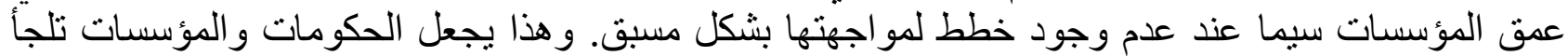

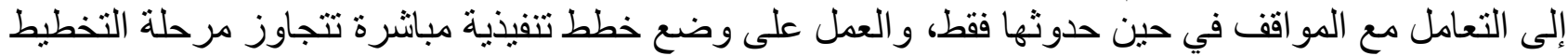

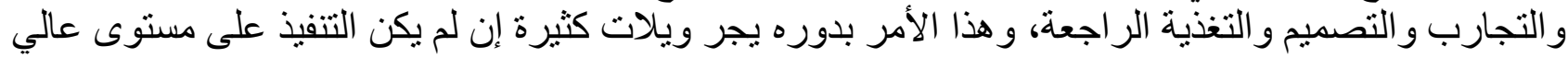

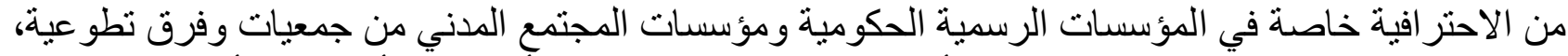

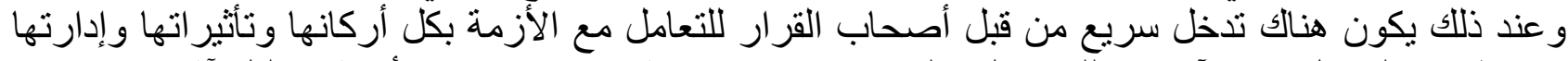

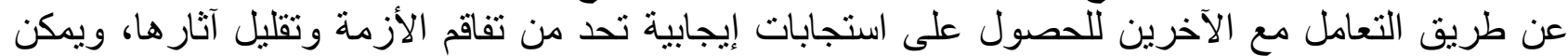
اعتبار إدارة الأزمات على أنها مجموعة من الآليات التي تعمل على حل مشكلة ما وفق طرق ملى محددة تم مناقثتنها

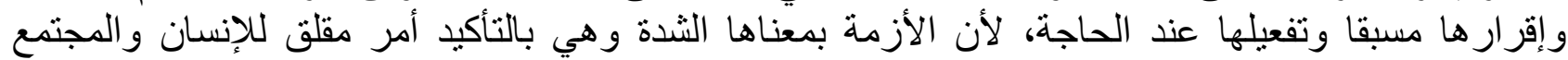

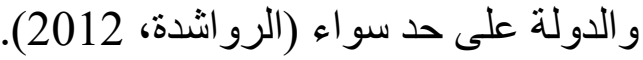

تدخل الأزمة العالمية الصحية التي أثرت على العالم من خلال انتشار وباء فيروس كورونا (covid-19) لتحل

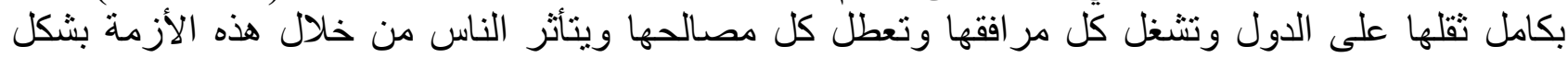

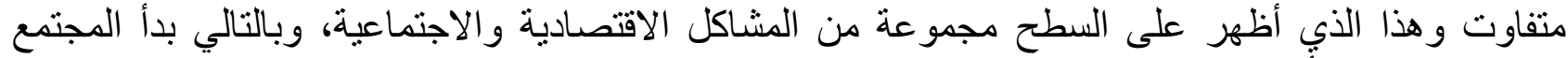
بالاستجابة لهذه الأزمة بمجمو عة من الخطو ات الفردية الفردية والمجتمعية والرسمية الحكومية من خلال نشكيل اللجان

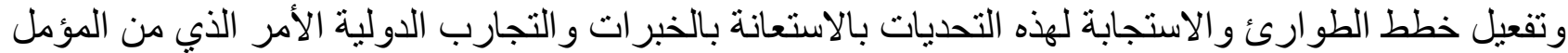

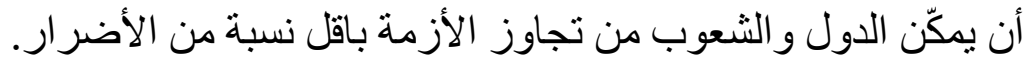

وحيث أن سلطنة عمان جزء لا يتجزأ من هذا العالم فقد تأثرت بشكل مباشر بهذه الأزمة الصحية من خلال

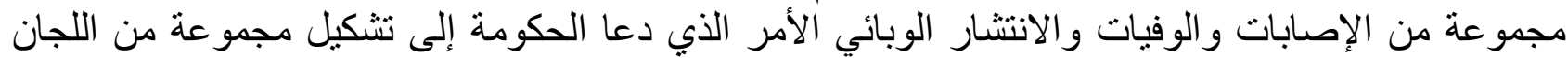

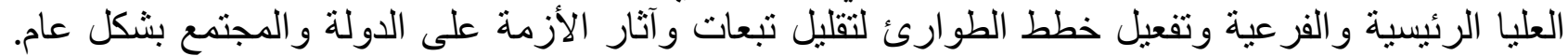

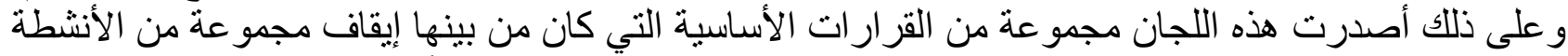

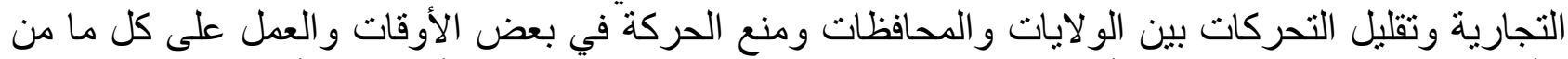

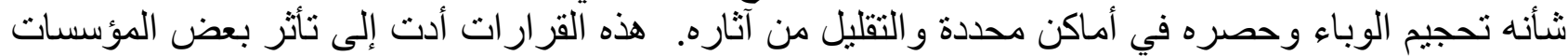

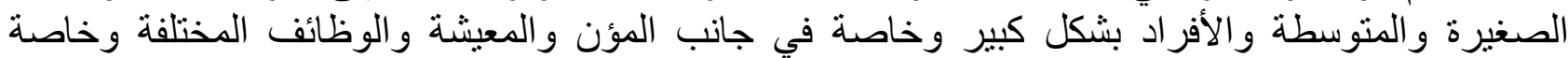

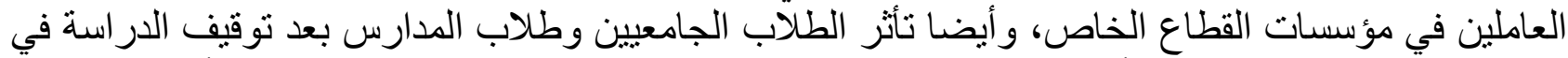

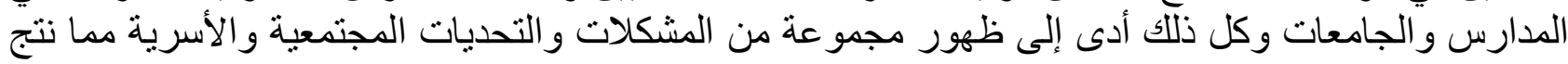
عنه اختلال في الجو انب الاجتماعية و الاقتصادية للفرد و المجتمع. 
المتطوعون جزء لا يتجزأ من المجتمع فهم يؤثرون ويتأثرون بكل ما يحدث من تطورات للأحداث التي ألقت

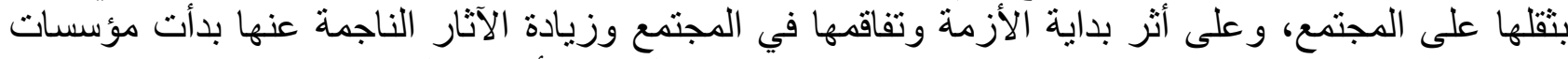

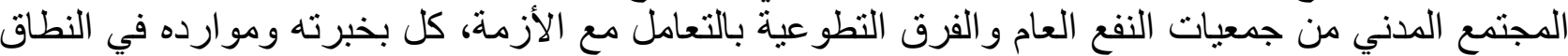

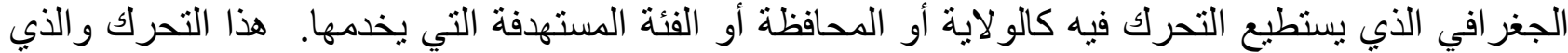

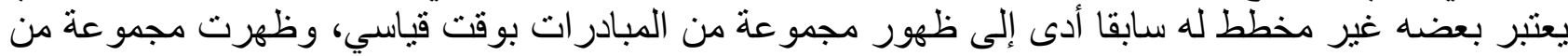

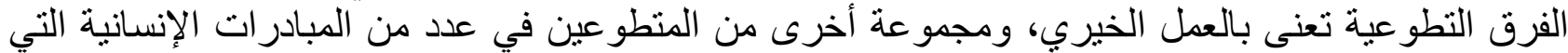

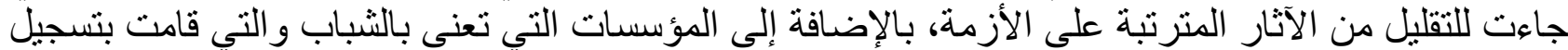

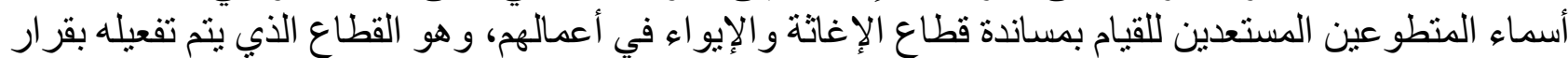

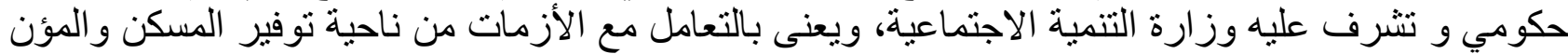

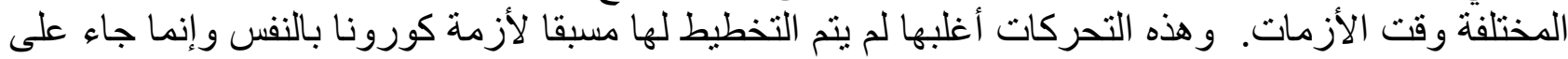

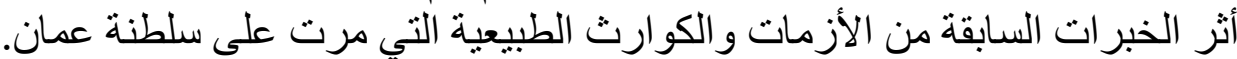

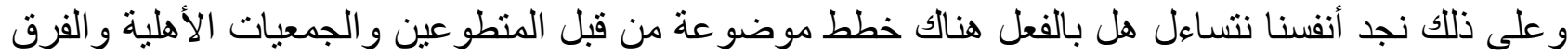

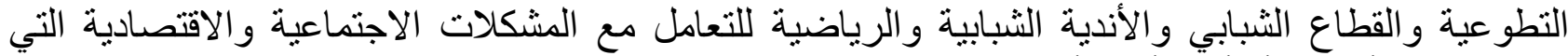

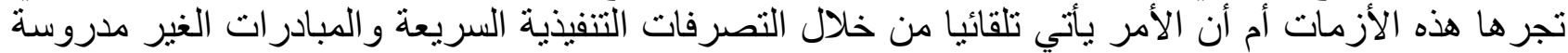

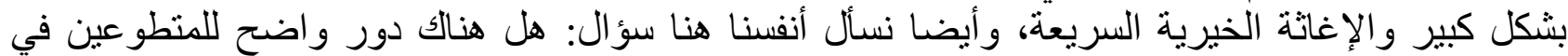

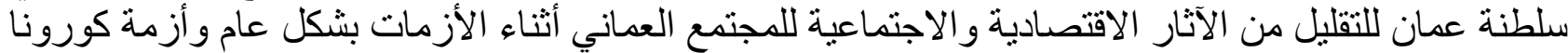

(Covid-19)

مشكلة الدراسة:

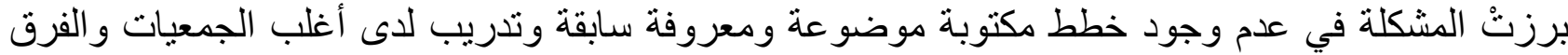
التطوعية في سلطنة عمان، لتفعيل دورهم ودور الأفراد والمتطوعين في في التقليل من الآثار الاجتماعية

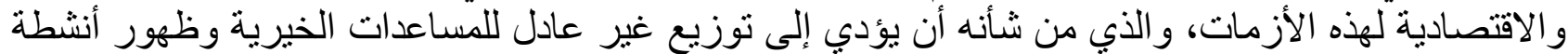

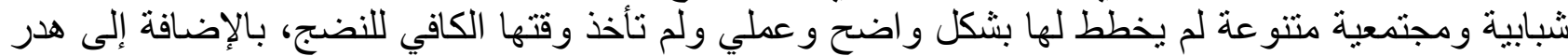

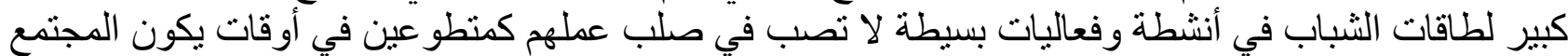

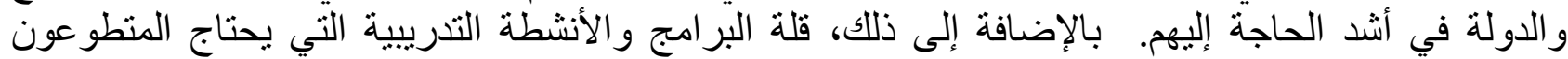
للتعامل معها مسبقا من ضدن بر امج التأهيل والتدريب التي تصقل خبر اتهم ومهار اتهم في الحياة التطو عية.

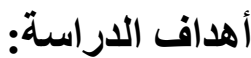

أ. الكثف عن الدور الحقيقي الذي يقوم به المتطو عين في الأزمات العالمية والمحلية.

ب. تحليل مو اطن القوة والضعف في خطط الطوارئ الخاصة بالجمعيات و الفرق التطو عية. ت. وضع مجمو عة من التوصيات و النتائج لتفعيل و اضح لدور المتطو عين و الجمعيات و الفرق التطو عية في التعامل مع الأزمات بشكل علمي ممنهج من الجو انب الاقتصادية و الاجتماعية.

الإطار النظري والدراسات السابقة:

أولا: الأزمة

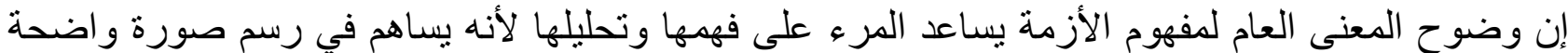

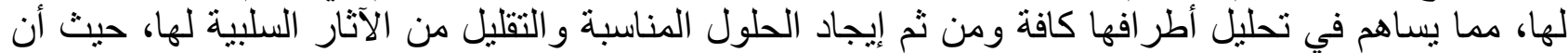

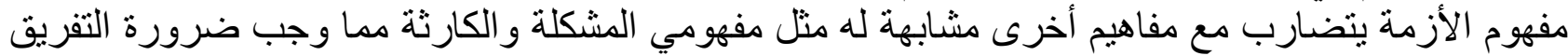

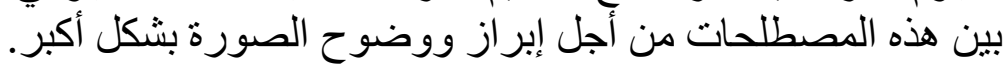

تعريف الأزمة:

قام الرازي (1999) بتعريف الأزمة لغويا على أنها الضيق في كل شيء سو اء أكان في طريق أو حياة أو عمل. 
أما كامل (2005) فقد عرف الأزمة على أنها نقطة التحول الحاصلة في حياة المجتمعات والثعوب وقد يكون هذا التحول إما توجها إيجابيا أو توجها سلبيا خلال فترة فلمة زمنية قد تطول أو تقصر.

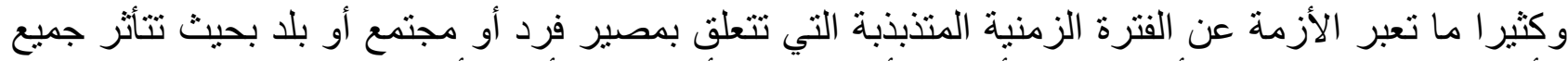

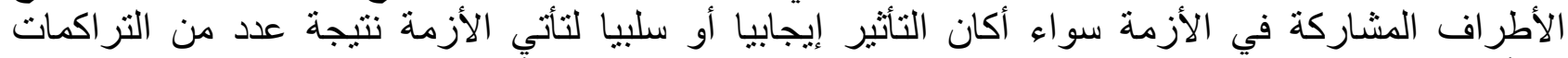
والتأثيرات التي تتسبب بحدوث خلل ما مما يؤثر على سير الحياة الأساسية وشكل تهديدا واضحا عليها (هلال،2004).

أما الأزمة كمصطلح فهي حالة من التوتر التي تصبب الفرد أو المجتمع لتتطلب منه اتخاذ قرار ينتج عنه عدد التها

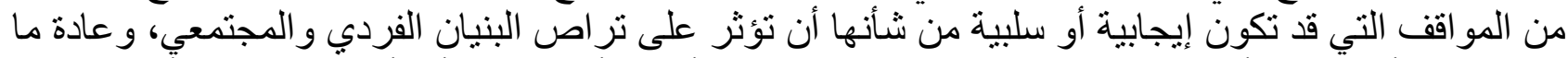

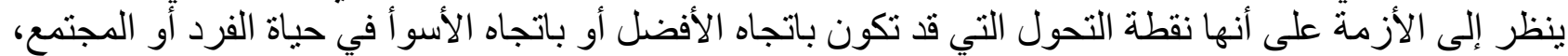

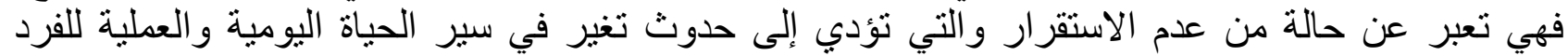

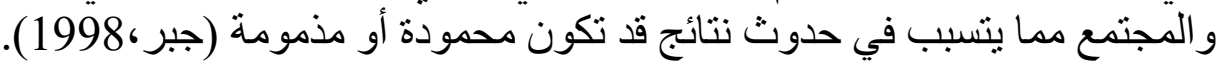
و اجه الباحثون صعوبة في توحيد تعريفاتهم للوصول إلى مصطلح واحد شامل وموحد وذللك بسبب صعوبة

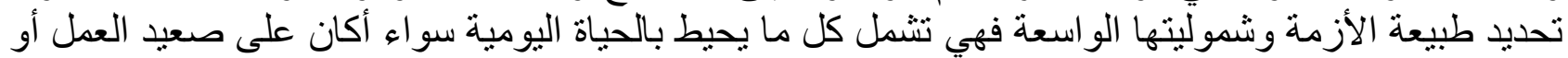

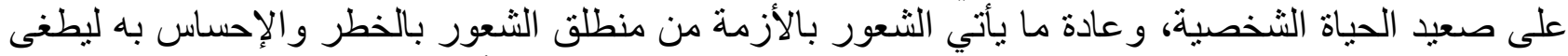

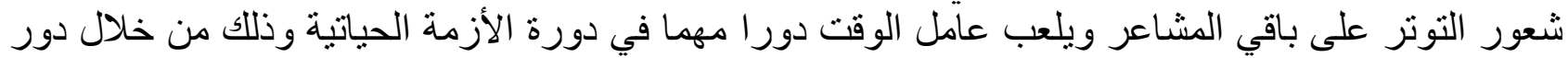

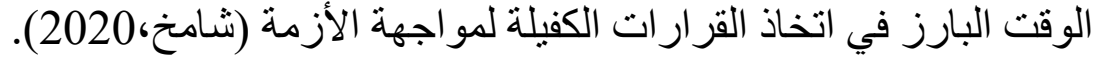

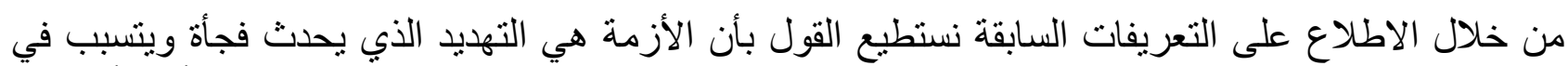

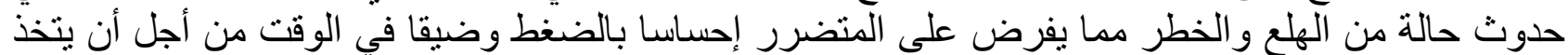

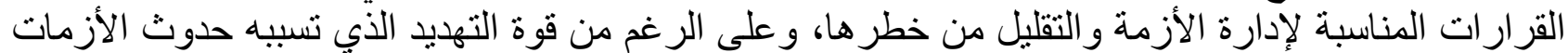

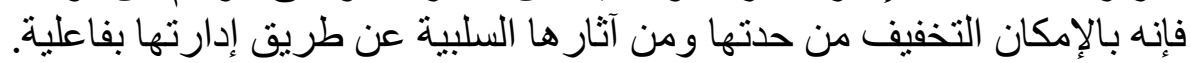
خصائص الأزمات: ذكرت عتيق (2013) مجمو عة من الخصائص التي تتميز بها الأزمة ومنها: نقطة تحول وتزيد فيها ردة الفعل لمو اجهة الظروف.

$$
\text { شعك عالي في القرار ات المطروحة. }
$$

يغلب عليها نقص المعلومات و عدم وضوح الرؤية و الثكك و الغموض.

قلة الوقت و الحاجة إلى اتخاذ قرار ات سريعة.

$$
\begin{aligned}
& \text { تهديد المصالح و الكيانات. } \\
& \text { تأثر سمعة متخذي القرار. } \\
& \text { السر عة و المفاجأة. } \\
& \text { التداخل في العو امل و الأسباب. } \\
& \text { ظهور حالات متعددة من الخوف و القلق. }
\end{aligned}
$$

تمر الأزمة خلال دورتها الحياتية مثلها مثل باقي الظواهر بمر احل متعددة تبدأ بالو لادة لتتنهي بالاختفاء. المهر

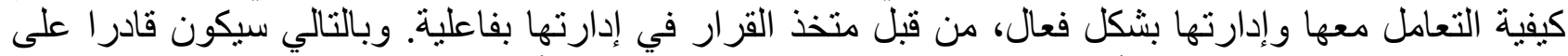

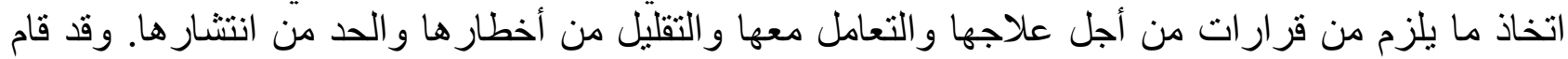
الخضيري (2003) بتقسيم مر احل الأزمة إلى من خمسة مر مر احل هي: 


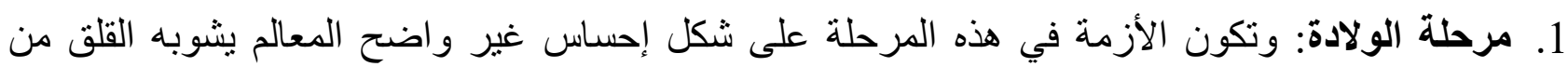

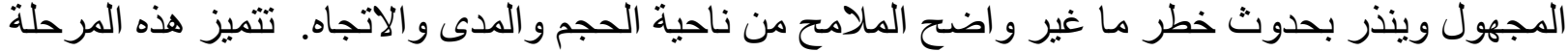
بغياب الكثير من المعلومات التي تتعلق بأسباب حدوث الأزمة وما ها هي المجالات التئ التي ستنمو فيها وماهي

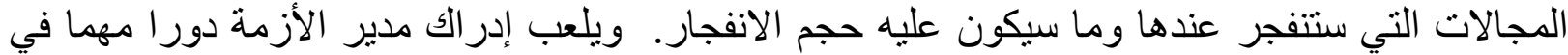

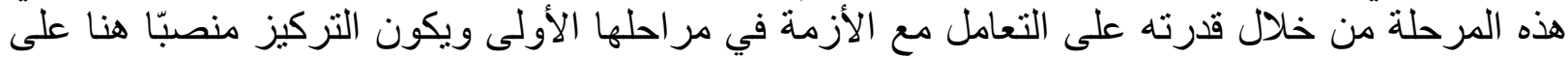

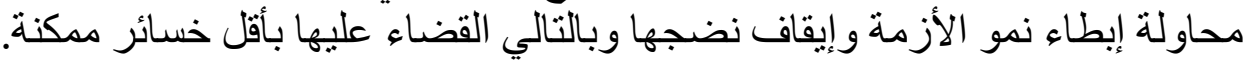

وتعتمد عملية الحد من انتشار الأزمة في مر احلها الأولى على عدد من الأسس، من أهمها: العمل على خلق محور من شأنه أن يحوّل الأزمة من شيء أساسي رئيسي ومهم إلى شيء ثانوي لا قيمة

التعامل بنجاح مع الأزمة من شأنه أن يقضي على أسباب التوتر والثعور بالتهديد وذللك من خلال معرفة ما هي العو امل المسبية لنشوء الأزمة و الوسائل المحتملة للتعامل معها بفاعلية.

تشتيت قوة دفع الأزمة وتوزيعها إلى أجزاء مما يساهم في امتصاص قوتها.

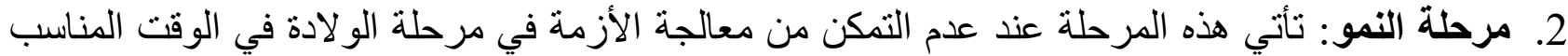

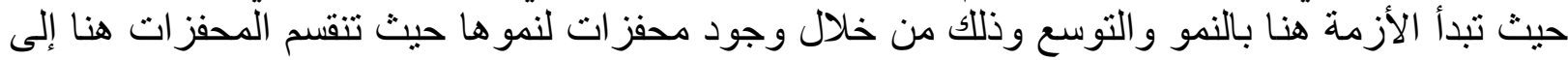
نو عين هما:

المحفز ات التي تكونت مع نشأة الأزمة في مرحلة الو لادة وتسمى بالمحفز ات الذاتية.

المحفز ات التي تفاعلت مع الأزمة و أضافت لها قدرة على النمو والاتساع وتسمى بالمحفز ات الخارجية. في هذه المرحلة يرتفع الإحساس بالمشكلة ولا يستطيع الإنسان نكران وجودها أو تجاهلها وذللك بسبب زيادة

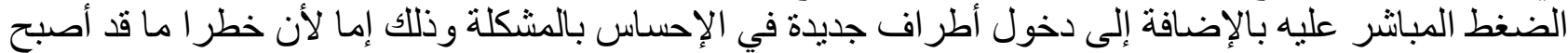
يهددهم أو بسبب الخوف من نتائجها التي قد تؤثر بشكل مباشر عليهم. و ويلعب مدير الأزمة دورا مهما في هذه فالها

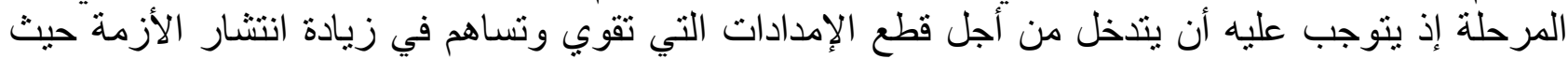
يتوجب عليه القيام بما يلي:

عزل العناصر الخارجية التي تساهم في تغذية الأزمة سو اء أكان عن طريق جذبها أو المساهمة في خلق التعارض بينها وبين نمو الأزمة التئ.

تجميد عو امل النمو الذاتي للأزمة ومحاولة إيقافها عند المستوى الحالي لهاو عدم السماح لها بالنمو أكثر. 3. مرحلة النضج : تعتبر مرحلة النضج من أخطر المراحل التي تمر بها الأزمة ونادر ا ما تصل الأزمة إلى

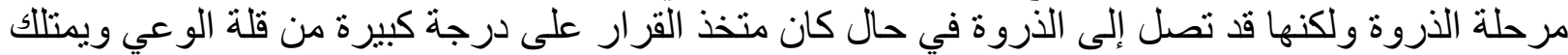

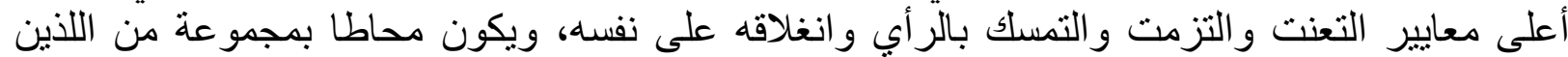
يقومون بتحسين صورة أخطاء المدير مما يتسبب في وصول الأزمة إلى أقسى صور ها وتصبح عملية

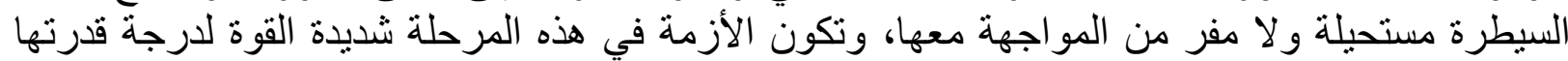

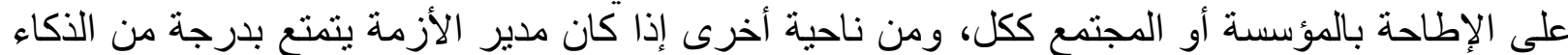

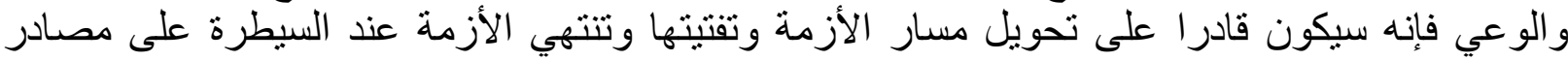
تغذيتها.

4. مرحلة الاتحسار: تبدأ الأزمة في هذه المرحلة بالتر اجع و الانحسار بسبب القيام بمو اجهتها بفاعلية مما يساهم في فقد الأزمة لمصادر قوتها ويحدث أحيانا أن تتجدد قوة الأزمة عندة علدما تفشل الإدارة في الحد من قوتها. 5. مرحلة الاتدحار والاختفاء: تصل الأزمة إلى هذه المرحلة عندما تفقد قوتها بشكل كامل حيث تختفي مظاهر

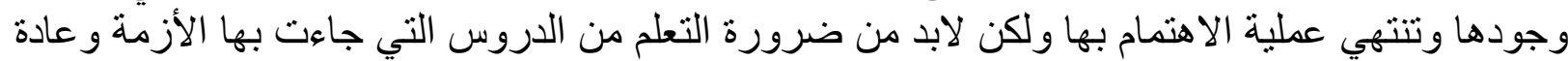
ما ينتج عن الأزمة في هذه المرحلة القضاء على عملية التكيف لأنها تصبح غير مقبولة لألة ويتم التركيز في هذه 
المرحلة على إعادة البناء و علاج الآثار التي خلفتها الأزمة وإعادة الحياة للجوانب المتهالكة جراء الأزمة و إكساب الإدارة مناعة أكثر وخبرة في كيفية التعامل مع الأزمات.

أسباب حدوث الأزمات:

تختلف كل أزمة عن غير ها من الأزمات وذلك تبعا لأسباب حدوثها، ولم يستطع الباحثون تحديد ماهية الأزمة

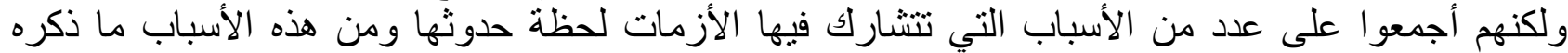
(اللامي و العيساوي، 2015):

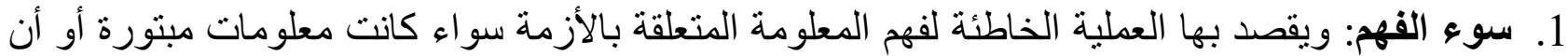
تسرع في إصدار حكم أو قرار قبل التحقق ويمكن أن يحدث هذا الامر نتيجة القلق أو التوتر أو لرؤية النتيجة بشكل عاجل.

2. سوء الإدراك: الإدر الك بمعنى استيعاب المعلومات و الحكم التقديري عليها، والسوء في الإدر الك ربما ينتج من التشويش الطبيعي لدى متخذي القرار أو حتى التشويش المتعمد من الجهات الدافعة بالأزمة مما يؤدي الأبي

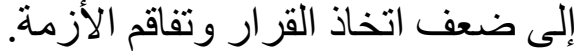

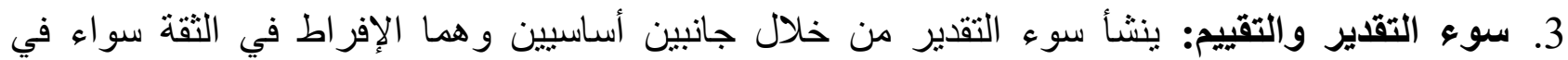
الإمكانيات أو العتاد أو العنصر البشري و إلى سوء تقدير الجانب الآخر من الأزمة ومدى قوتئنه 4. الإدارة العشوائية: وهي الإدارة التي تدار عن طريث أهواء وعقليات لا تؤهن بالطرق العلمية وأساسيات

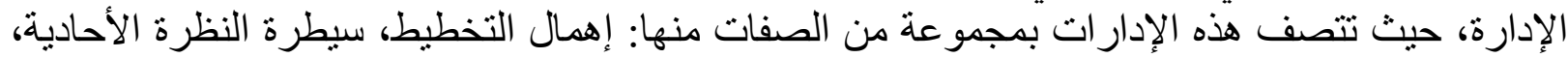

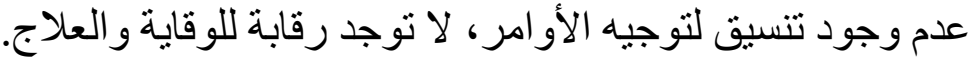

5. الرغبة في الابتزاز: وتأتي هنا جماعات الضغط والمصالح لجني المكاسب من خلال خلق أزمات متتالية

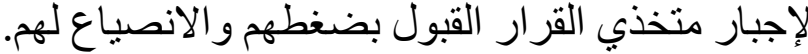

6. اليأس: وهو جانب نفسي يؤثر على متخذي القرار ويؤدي إلى الإحباط وبالتالي يفقده الرغبة بالتطوير

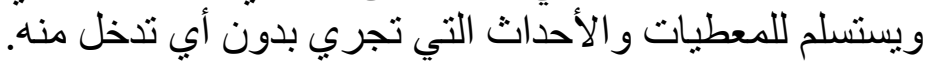

7. الإشاعات: حيث تعتبر أهم مصدر من مصادر الأزمات، حيث تكون في العادة معلومات خاطئة أو كاذبة يتم

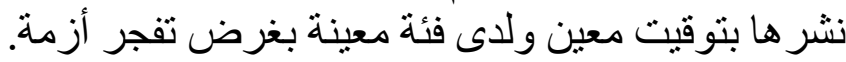

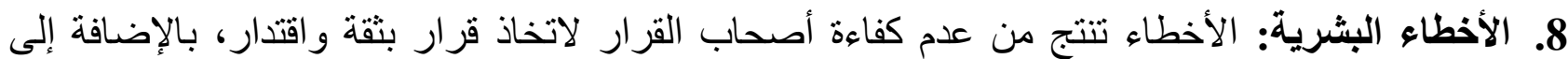

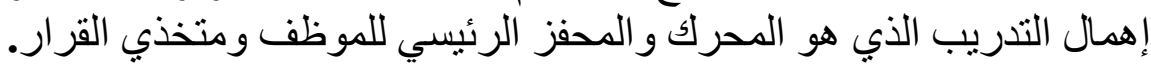
9. استعراض القوة: يمارس من قبل الكيانات الكبيرة ضد الكيانات الصغيرة، باستغلال للمواقف والظروف للتأثير علينه.

10.تعارض الأهداف: وخاصة إذا كانت هناك أزمة تجمع عدد كبير من الأطر اف ويسعى كل واحد بدورة للتقليل

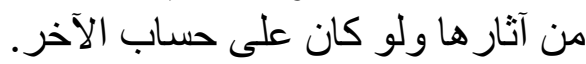

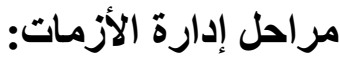

تمر الأزمات عادة بعدد من المر احل ولكن اختلف الباحثون حول ماهية الإدارة المناسبة للأزمة وذلك من خلادل كيفية إدارتها بالطريقة الصحيحة، قام عدد من الباحثين بتصنيف طريقة إدارة الأزمة إلى خمسة مراحل

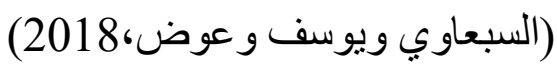

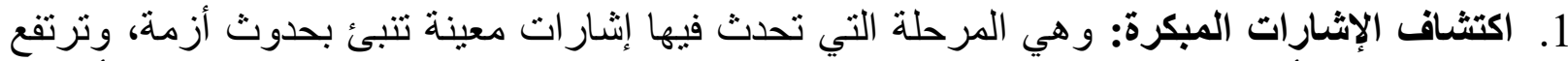

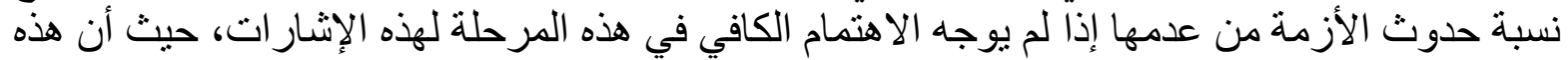
المرحلة لا توجد فيها خسائر واضحة ولكن هذه المرحلة تعلب دورا هاما في تشخيص المشكلة وتوقع 
2. الاستعداد: تتطلب هذه المرحلة الاستعداد الكامل من أدوات ووسائل وأجهزة وأساليب وتدريب لكل الئل

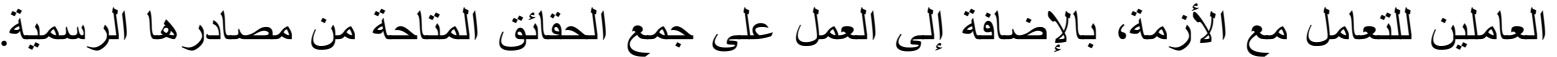
وتتلخص المرحلة بشكل عام في تحليل مو اطن القوة والإنة الضعف.

3. الاحتواء: وهي المرحلة التي تقوم فيها المؤسسات والمنظمات بتنفيذ الخطط للمواجهة الفعلية للأزمة و الحد من الآثار المترتبة عليها ومنع انتثار ها على نطاقات واسعة، بالإضافة إلى تقدير الخسائرة الخائر الناجمة

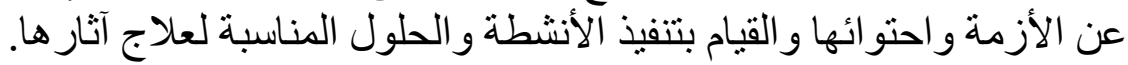
4. استعادة النشاط: وهي المرحلة التي يكون فيها استعادة الأنشطة وتشكيل فرق العمل الخاصة بإعادة البناء و إعداد خطط طويلة أو قصيرة الأمد العد لاستعادة النشاط. 5. التعلم: و هي المرحلة التي توثق فيها الدروس الخاصة للاستفادة من الأزمة وتحسين ما تم إنجازه و البناء

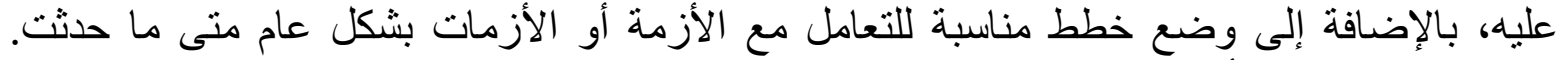

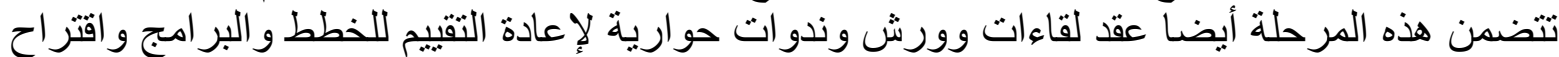

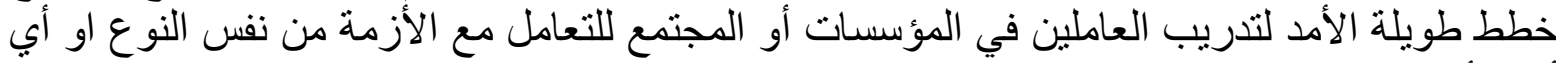

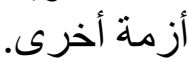

في فترة حدوث الأزمات تمت ملاحظة انخفاض كبير في المعايير الاجتماعية وضعف في سطوة القيم التي كان الفرد يتمتع بها قبل حدوث الأزمة وخلال مسيرته الحياتية ككل منذ بداية نشأته، حيث لاحظ الباحثون أنه عند

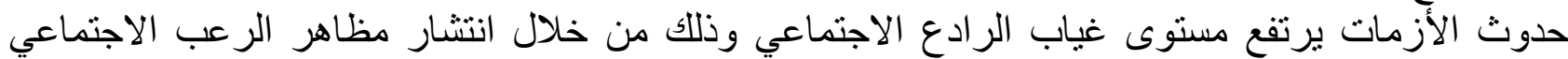

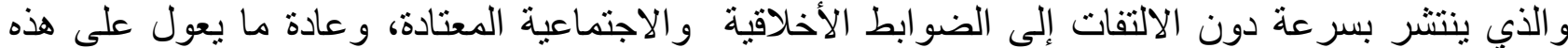

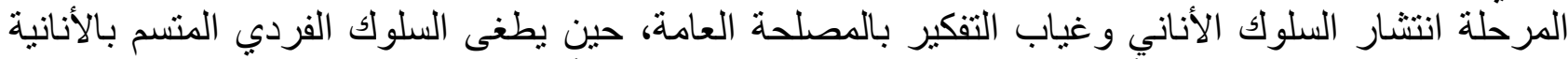

المتمتع بالانتفاع الفردي، دون أي لجوء إلى عمليات التخطيط وبدون الأخذ باعتبار ات المصلحة العامة.

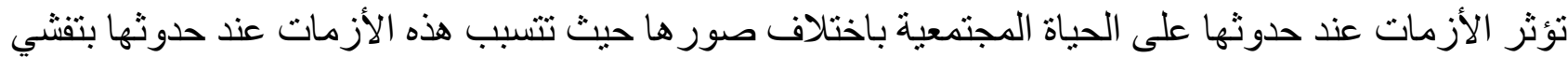

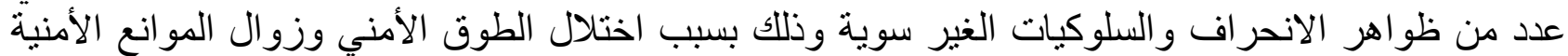
بالإضافة إلى تأثثرها على الهرم السكاني المكون للمجتمع وذللك من خلال ارتفاع عدد الأرامل و المطلقات

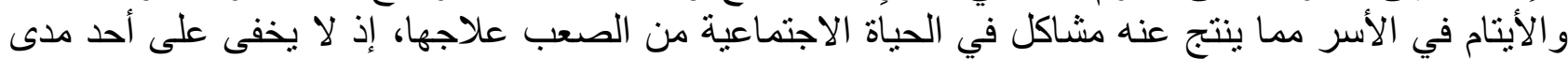
الارتباط الوثيق بين النشاط المجتمعي وانتشار الأمن في المجتمع، حيث تقوم الأزمة بالتأثير المباثر على الألى الحياة

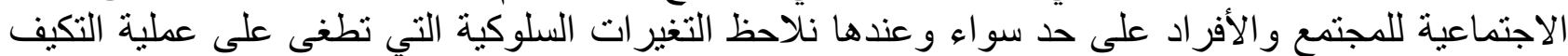

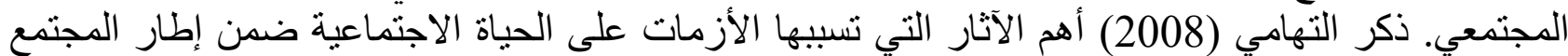

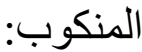

التأثير المباشر على مستوى معيشة الفرد ضمن نطاق الأسرة وذلك من خلال فقدان المعيل الأساسي للأسرة. الرغبة في إثباع الحاجة إلى الأمن والأمان في ظل غياب الشعور بالأمان المجتمعي. انتشار الاستهتار و عدم المبالاة فيما يتعلق بالثؤون العامة وفقدان الأمل في الحصول على حياة أفضل. توقف سوق العمل بشكل جزئي أو كلي مما بساهم في انتشار البطالة. ارتفاع مستوى الشعور بالتشتت الاجتماعي بسبب تنقل معيل الأسرة بشكل دائم ما بين مناطق الأزمة. إصابة عدد من أفراد المجتمع بما يسمى بالرهاب الاجتماعي وتفثيه بشكل كبير بين الأفراد خلال فترة الأزمات. ارتفاع مستوى الانحر اف الاجتماعي بصوره المختلفة ما بين الأفر اد. 
انخفاض القدرة على التأقلم مع الذات البشرية والأشخاص و البيئة المحيطة بالفرد.

لا تقتصر عملية حدوث الأزمات على الآثار السلبية لها بل لاحظ الباحثون وجود جانب مشرق لها، تجلى إنلى هذا

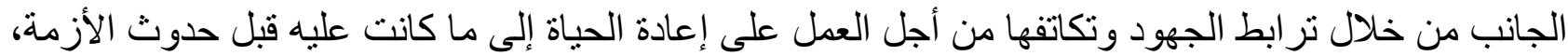

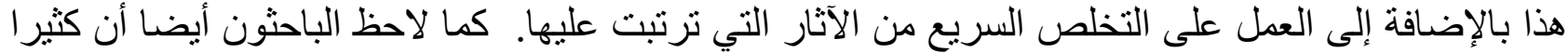
من الأزمات تقوم بتوليد روح التعاون وتعزز من أهمية عملية التكاتف و التعاضد ونبذ التبات الخلافات وبالتالي تحقيق التيق

التكافل المجتمعي.

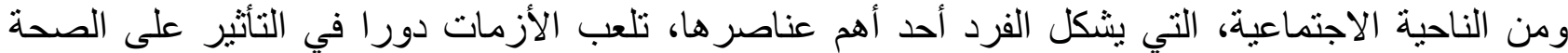

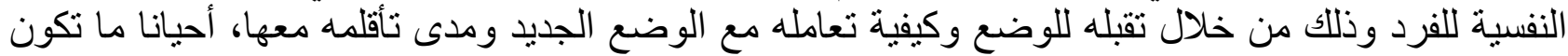

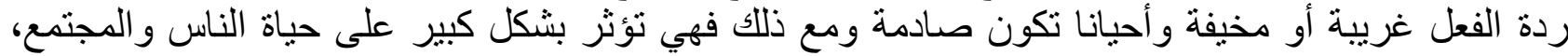

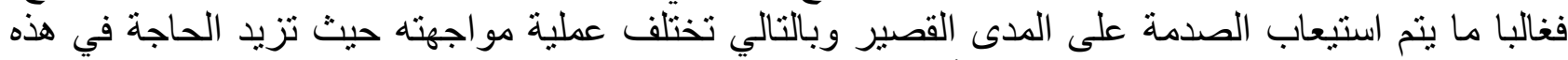

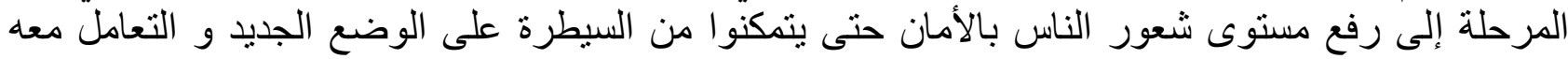

بطريقة صحيحة.

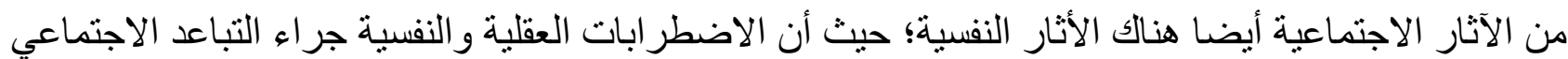

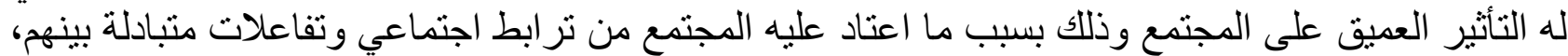

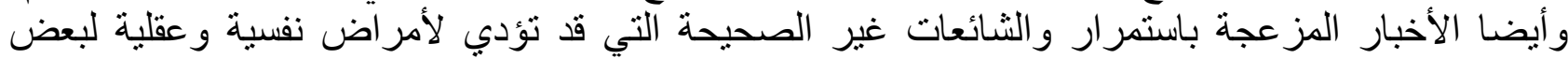

الحالات البشرية في المجتمع (Singh,2020)

الآثار الاقتصادية:

تلعب الأزمات دورا مهما وكبيرا على الحياة الاقتصادية سواء أكان على حياة الفرد أو المجتمع حيث تقوم

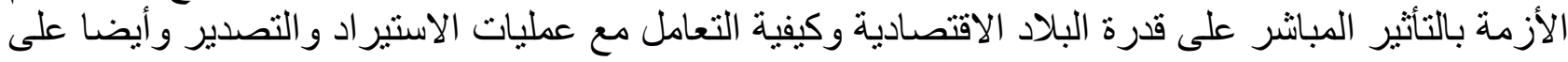

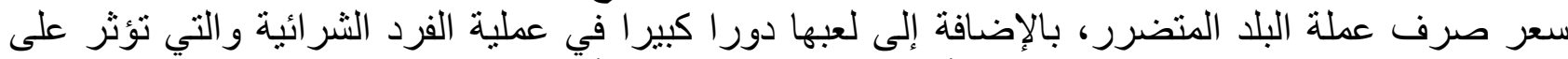
الحركة الاقتصادية للبلد بشكل عام، وتتجلى أبرز الآثار الاقتصادية للأزمات بالنقاط التالية (الفر ا، 2020):

انخفاض الطلب على المنتجات و السلع الاستهلاكية: حيث يلاحظ خلال فترة الأزمات قلة الطلب على دلى دلى المنتجات وذللك بسبب تأثثر الأزمة المباثر على دخل الفرد مما يساهم في ضعف قوته الثر ائية.

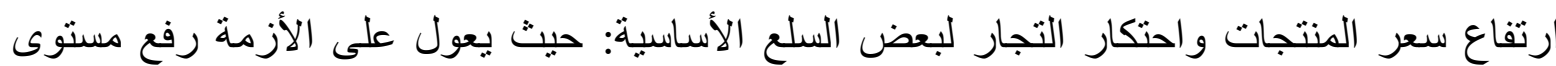

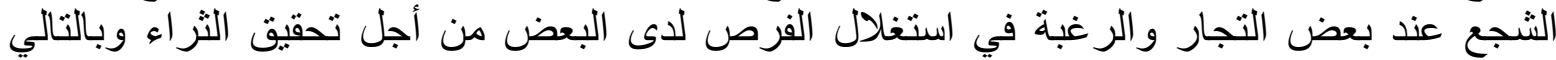
ارتفاع سعر المنتجات والتحكم في وجودها بالسوق بطريقة تفوق قدرة الفرد.

انكماش حجم السوق اقتصاديا: بحيث تصبح الدولة غير قادرة على التوسع في الأسواق التجارية،

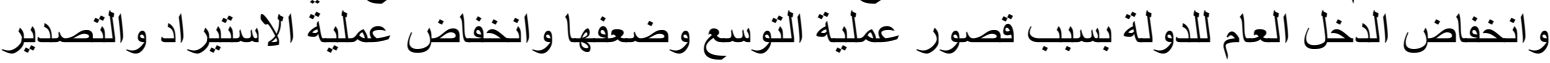

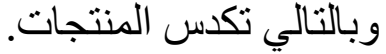

انخفاض مستوى الائتمان: عادة ما تتخفض القيمة الائتمانية للبضائع بفعل الأزمات بحيث تضعف عملية

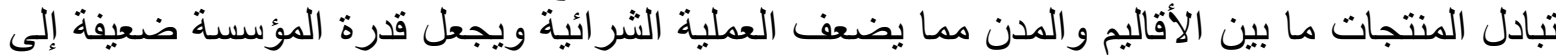

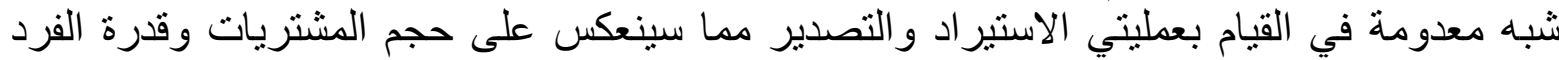
الشر ائية التي يقوم بها عادة.

التذبذب في سعر العملات: غالبا ما تؤثر الأزمة على قوة عملة البلد المتضرر بسبب ارتباط سعر التهر

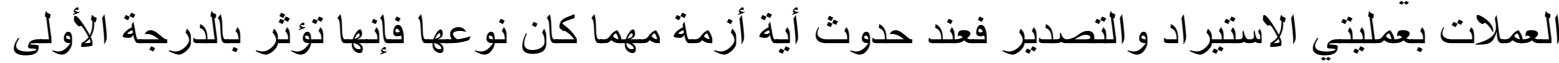

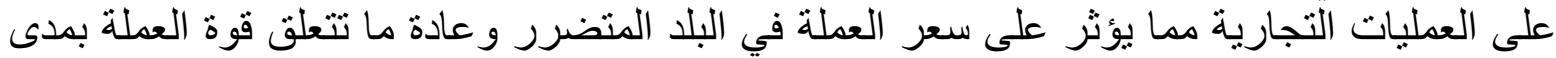

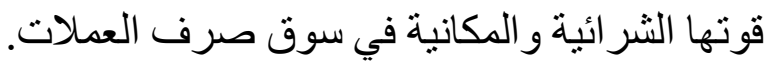
ارتفاع مستوى عمليات النصب و الاحتيال ما بين الأفر اد. 
تسريح العاملين في عدد من المؤسسات بسب ضعف الإقبال على منتجاتها من قبل الأفراد.

جائحة كورونا (Covid-19)

كورونا (Covid-19)

وضعت منظمة الصحة العالمية مبادئ توجيهية لتصنيف انتقال العدوى وتعريفات محددة للمر اقبة من أجل إعلام الجمهور و البلدان لاعتمادها لتحديد الحالات بحيث تلتزم البلدان و المناطق بالإبلاغ عن الحالات (منظمة الصحة العالمية، 2020):

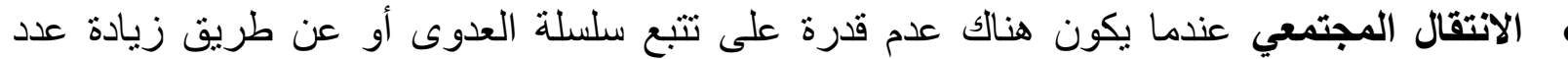

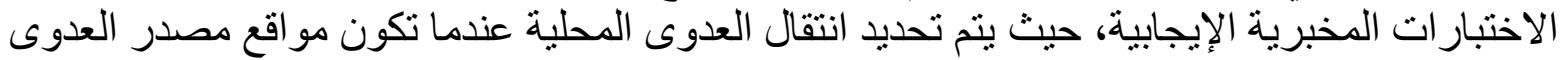
داخل منطقة الإبلاغ، بينما تكون الحالة المستوردة فقط عندما تنتقل العدوى لجميع الحالات من خارج

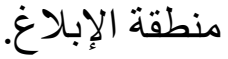

قيل البحث هو عندما لم يتم تحديد نوع انتقال العدوى بعد لأي حالة، ويكون انتقال العدوى المتقطع عندما

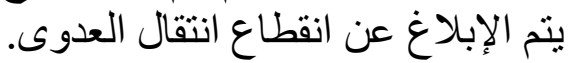

الحالة المشتبه بها هي الثخص الذبي يعاني من أعر اض تنفسية حادة بما في ذللك الحمى و علامة و احدة

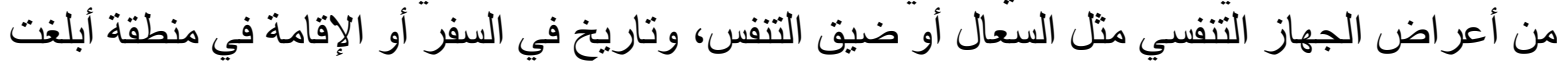

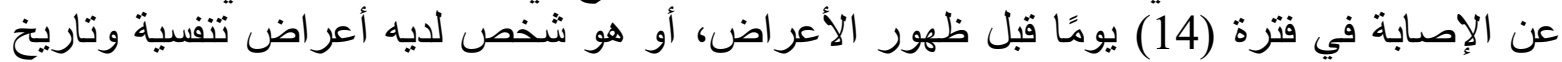

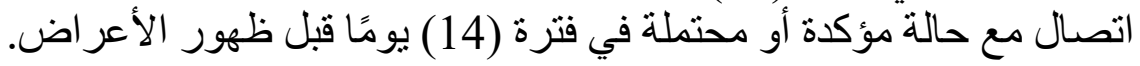

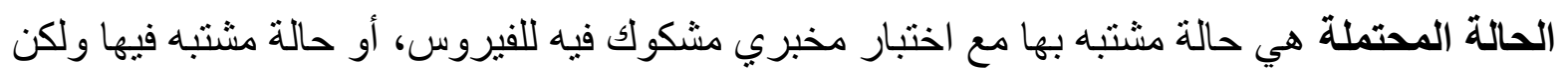

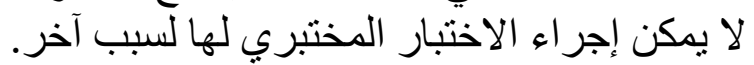
الحالة المؤكدة هو تأكيد الاختبار المختبري للفيروس بغض النظر عن الأعر اض الطبية. فترة الحضانة وهي المدة من الإصابة بالفيروس لحين بدء ظهور الأعر اض، وتكون ما بين يوم واحد إلى (14) يوم. الشخص المخالطِ هو الثخص الذي قام بالاتصال المباثر مع حالة محتملة أو مؤكدة على مسافة مثر

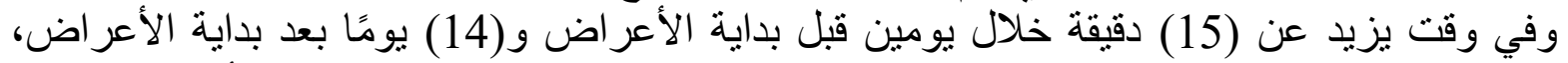

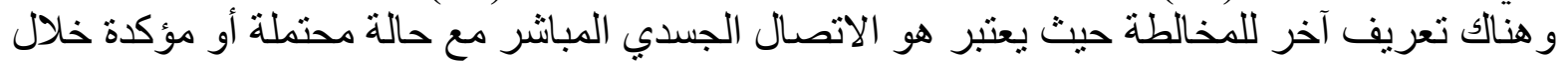

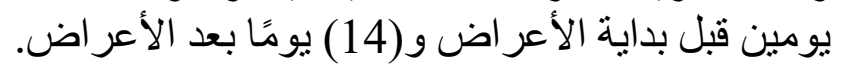

قد يصاب بعض الناس بالعدوى بدون ظهور أي أعر اض ونسبة كبيرة حوالي (80\%) منهم يتعافى من المرض

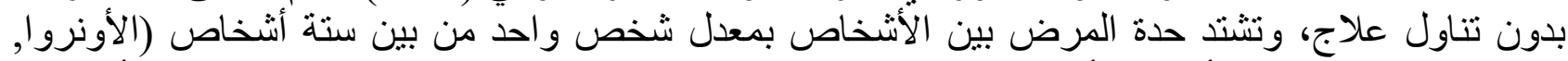

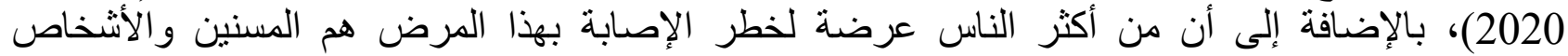

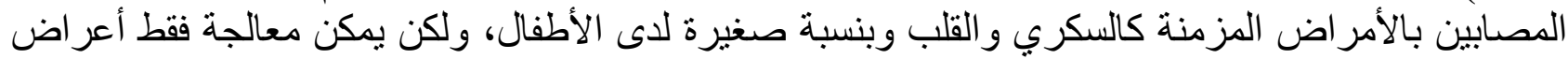
المرض (بيندير, 2020).

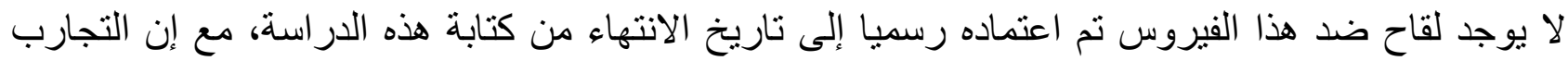

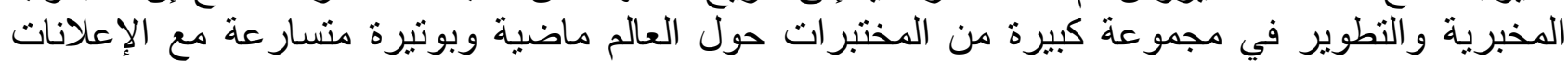
المتتالية عن انتهاء التجارب في في مر احلها الأولى و التخانية.

استحدثت منظمة الصحة العالمية استراتيجيات عامة واجتماعية مختلفة يجب اتباعها من أجل إبطاء أو وقف وقاء

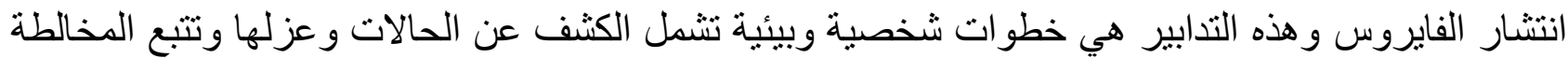

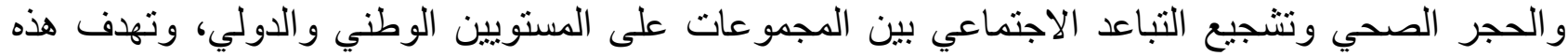

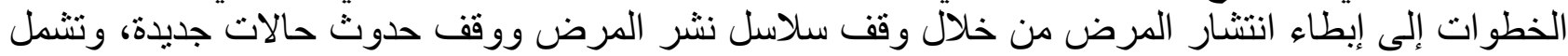


التدابير الأخرى وجود بيئة عمل مرنة منل التعليم والعمل عن بعد، بالإضافة إلى إغلاق المرافق غير الحيوية وحماية السكان الضعفاء وتدابير البقاء في المنزل.

وتعتبر سلطنة عمان من إحدى الدول التي تأثرت بهذه الجائحة المرضية ولقد اعلنت وزارة الصحة عن تسجيل

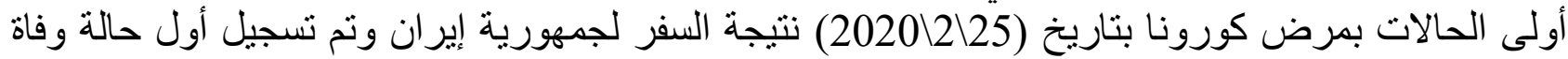

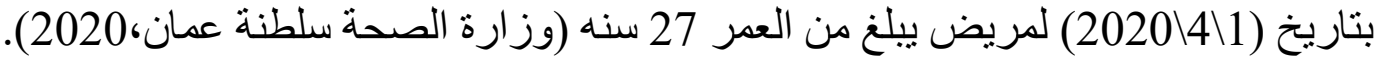

الآثار على المستوى الاقتصادي:

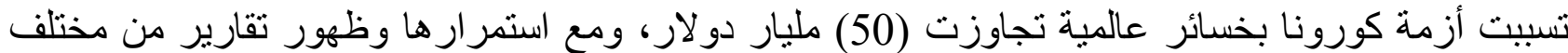

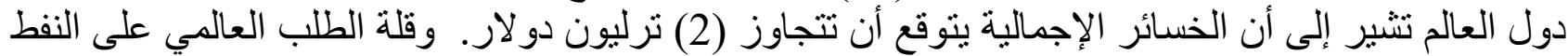

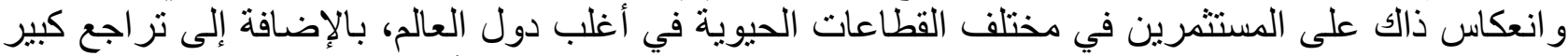

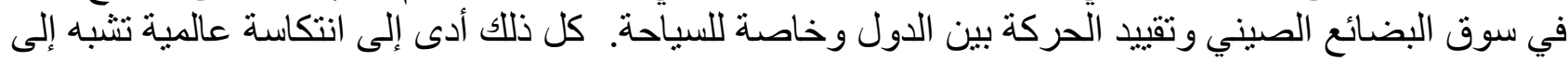
حد كبير الركود الاقتصادي لعام (2008) و الذي لم يتعاف العالم من تبعاته بعد، ومر اكز بحثية اقتصادية التهادية كثيرة

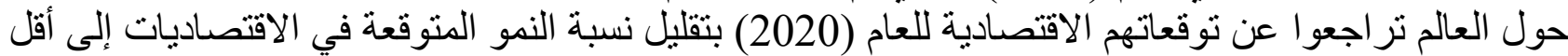

معدلاتها (اليو انسة، 2020).

كل هذه التطور ات أدت إلى تأثر كافة قطاعات الدول اقتصاديا وتأثر الأفر اد بشكل مباشر إما من خلال تسربحهم

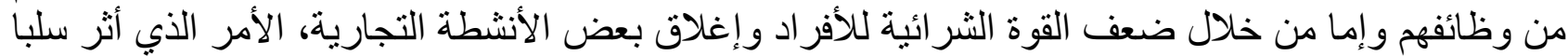

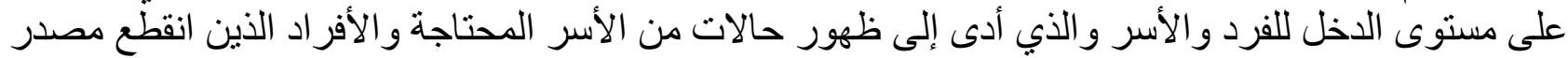

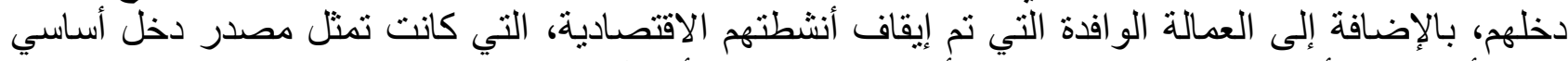

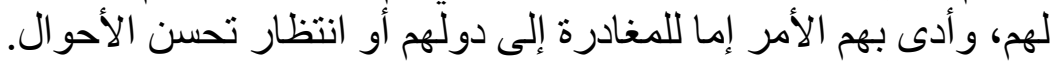

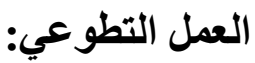

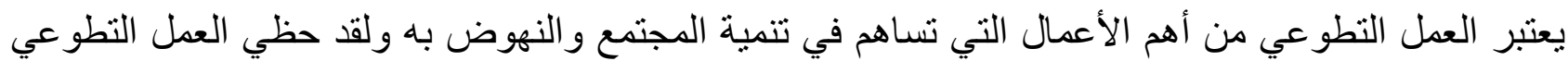

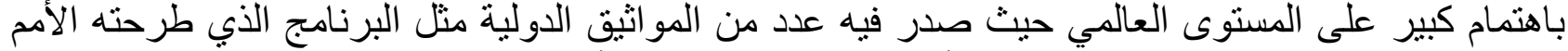

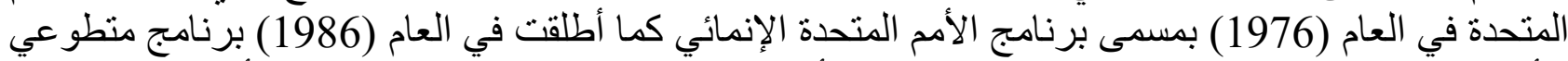

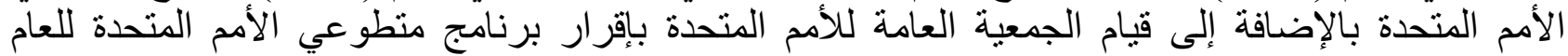

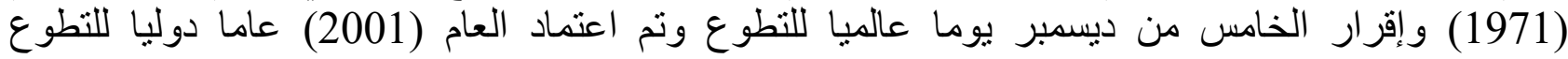

(عباس،2019).

عرف العمل التطوعي على أنه أي عمل إنساني يقوم به الفرد عاكسا رغبته في تقديم خدمة ما للمتضررين مما

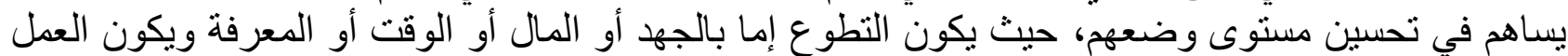

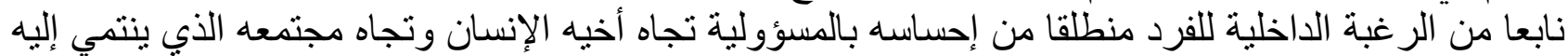

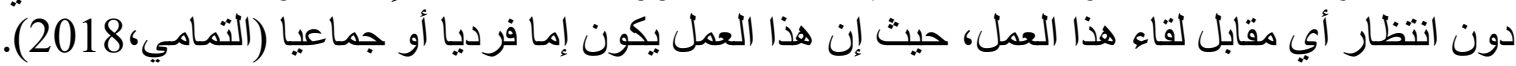

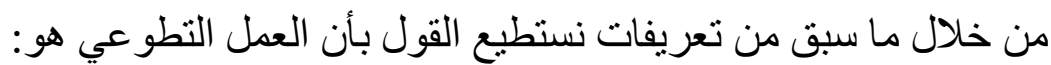
عمل إنساني يقوم به الفرد بمحض إر ادته دون انتظار أبي مقابل مادي له. يمكن للمتطوع أن يكون ذكر ا أو أنتى ومن أي جنسية أو ديانة. العمل التطو عي لابد أن يكون نابعا من الإر ادة المحضة للفرد في تقديم الأفضل لمجتمعه.

أشكال العمل التطوعي:

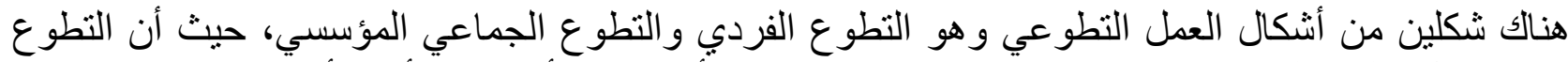

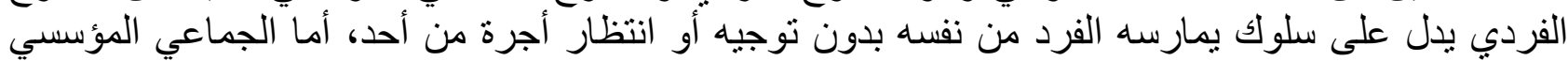

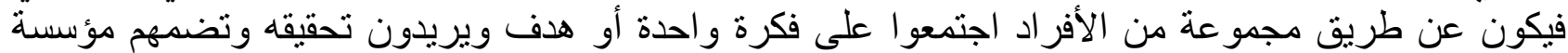

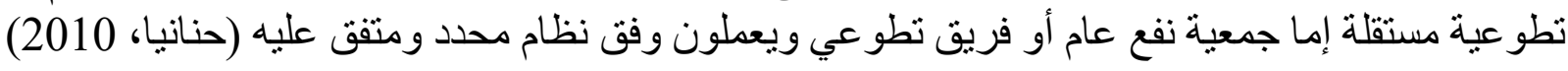




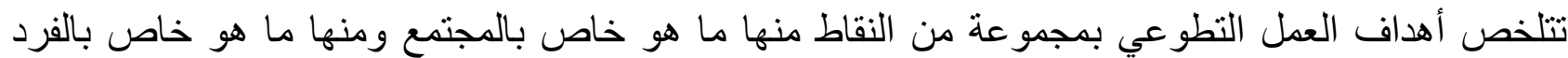

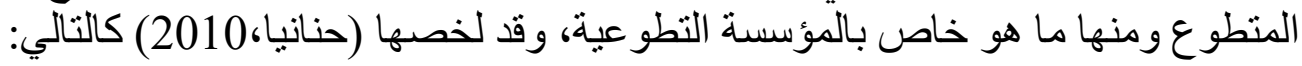

$$
\text { بساعد على تماسك المجتمع وتخفيف المشكلات الاجتماعية. }
$$$$
\text { زيادة رضا أفر اد المجتمع و إثباع حاجاتهم. }
$$$$
\text { التوعية بالظروف الو اقعية التي يعيشونها. }
$$

التفاف المتطو عين حول أهداف مجتمعية مرغوبة.

تنمية المجتمع وتحقيق التنمية الثشاملة.

استثمار المنطوع لأوقاته على أكمل وجها.

توجيه طاقات المنطو عين إلى الأعمال و الأنشطة المفيدة للمجتمع.

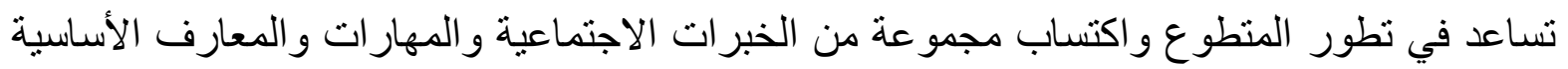
التي يحتاجها في حياته.

يقوي شعور المتطوع على الوطنية والانتماء.

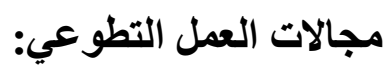

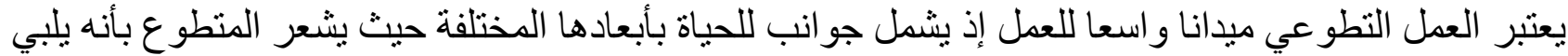
نداء الوطن دون انتظار أب مقابل مادي، قام عباس (2019) بذكر مجمو عة من مجالات العمل التطوعي منها:

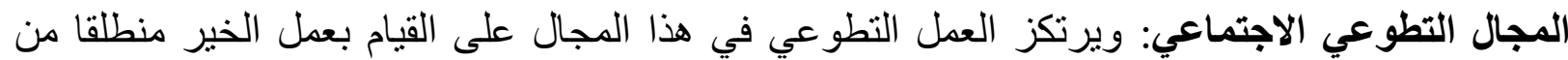

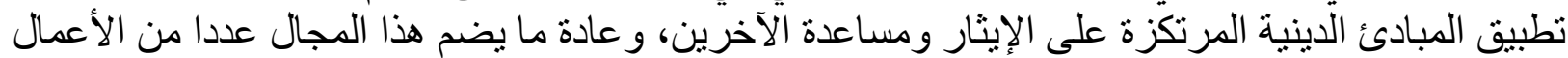

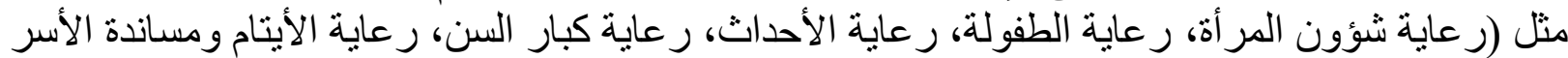

(المعسرة).

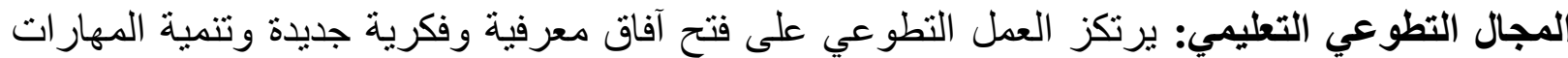

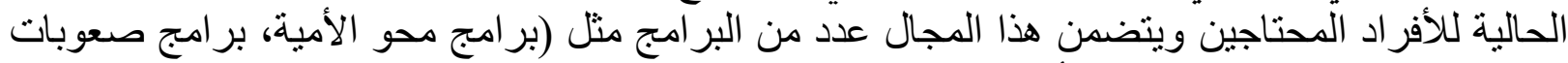
التعلم، وتقديم المعونة التعليمية للمتأخرين دراسيا).

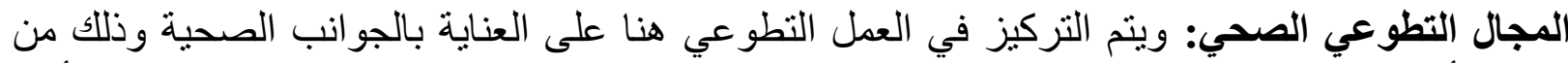

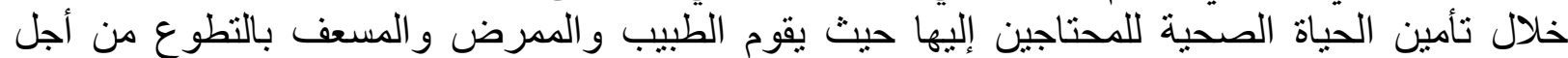

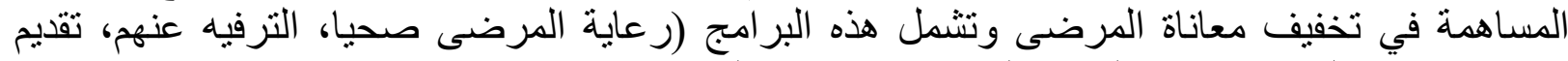
بر امج الإرشّاد الصحي، تقديم المعونة لذوي الاحتياجات الخاصة).

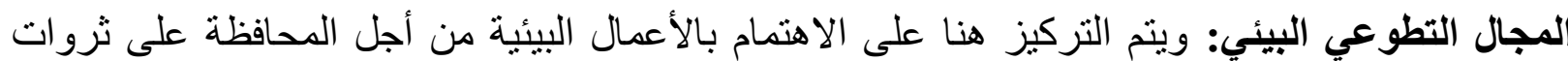

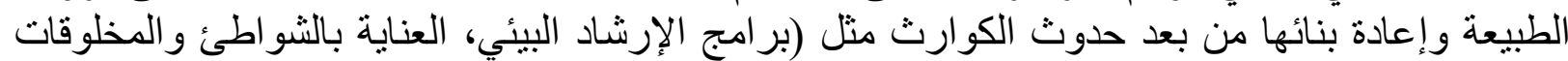
البحرية، العناية بالمنتز هات ومكافحة التلوث).

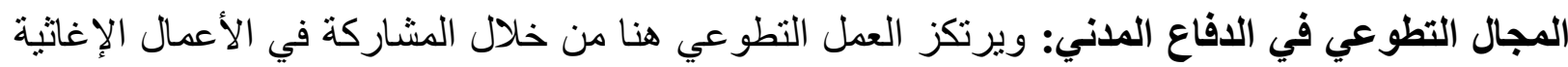
ومساعدة رجال الإطفاء و الإسعاف و التخفيف من معاناة المتضررين.

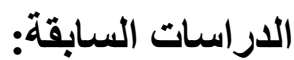

1. در اسة اكسي وآخرون (Xie et.al,2020) حيث تطرقوا في دراستهم حول الأزمات الصحية واعتبروا أنها

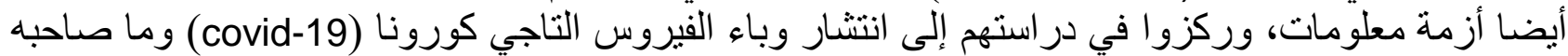




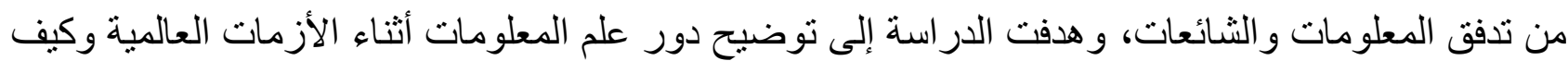

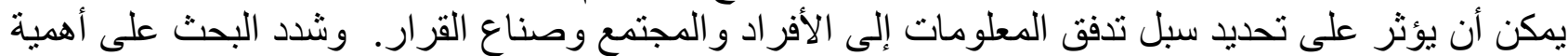

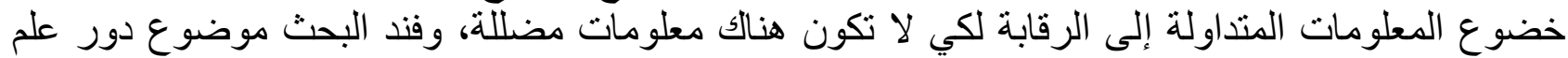

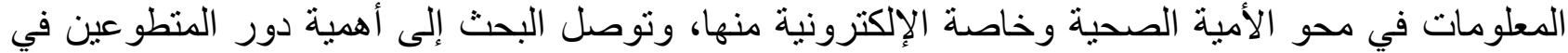

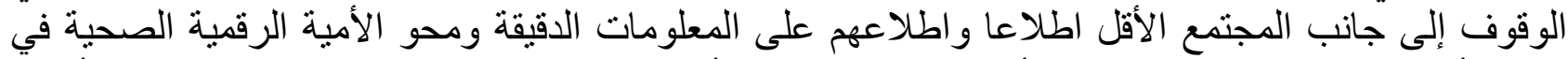
حال الأزمات الصحية وغير ها من الأزمات المختلفة، كما أوصى البحث بمجموعة من التهات التوصيات من أهمها

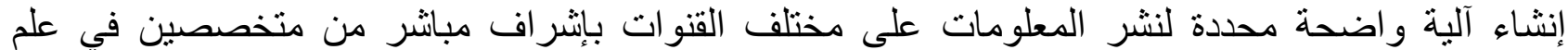
المعلومات، والاستفادة من المتطوعين المطلعين والخبراء في الجوانب المختلفة للمساعدة في ذلك وفق نظام محدد وو اضح للجميع.

2. (عتيق، 2013) هدف البحث إلى تركيز الاهتمام بالإطار المفاهيمي للأزمات من ناحية فكرة أن الأزمة

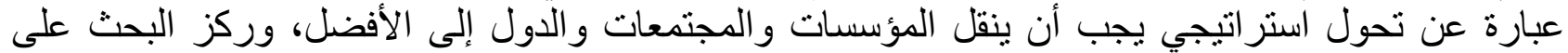

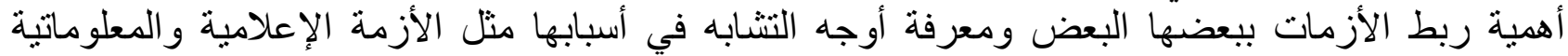

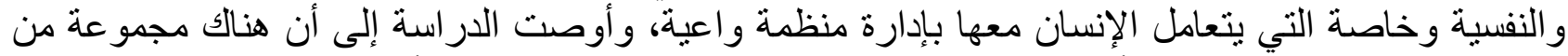

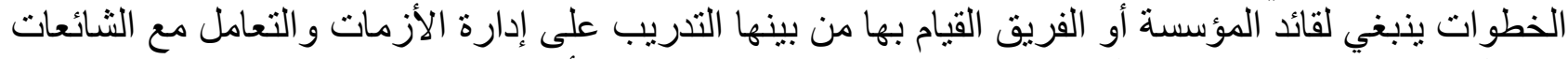

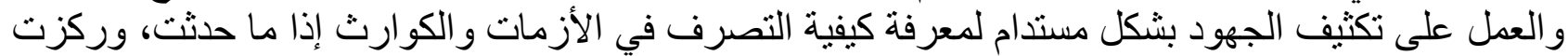

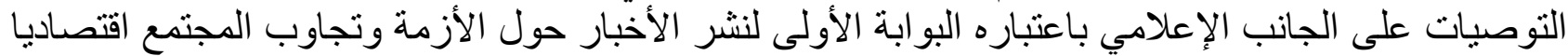

و اجتماعيا ونفسيا معها.

3.در اسة (Poole et.al,2020) جاءت من منطلق الأزمات الإنسانية المعقدة واستجابتها للأزمات الصحية في

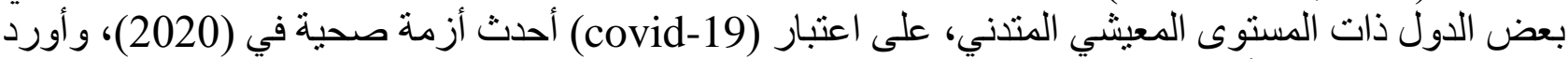

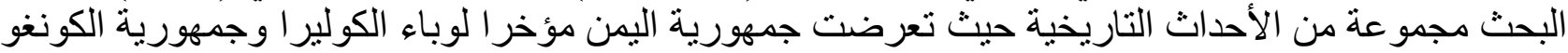

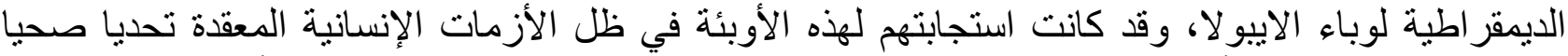

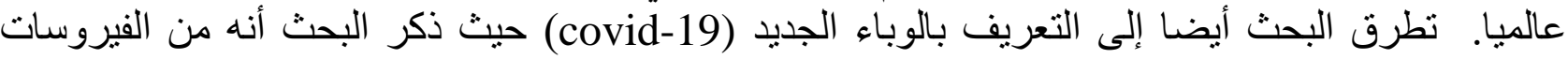

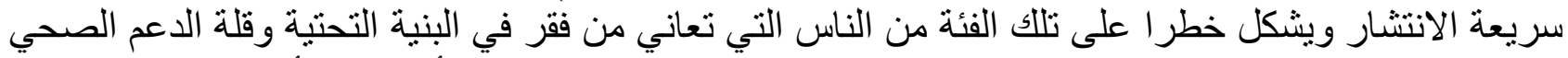

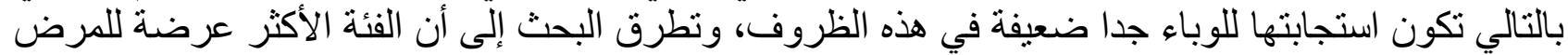

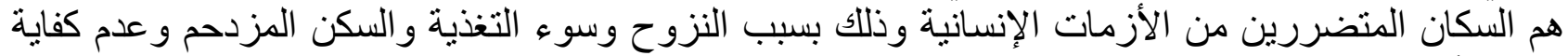

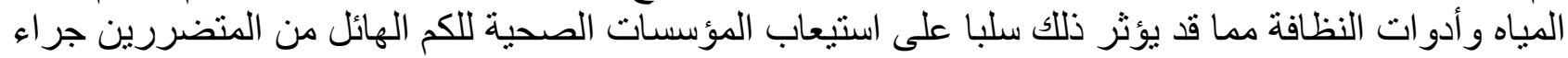

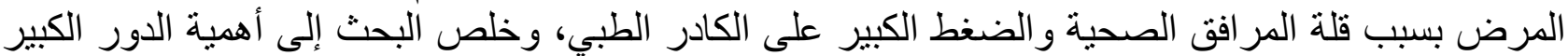

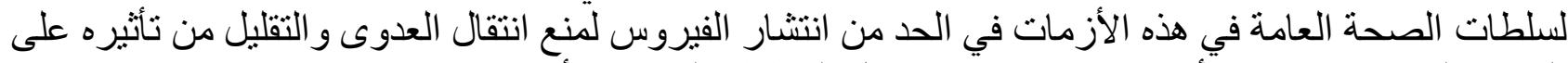
السكان المتضررين من الأزمات الإنسانية من خلاء الأمات الخطط و البر امج الأساسية.

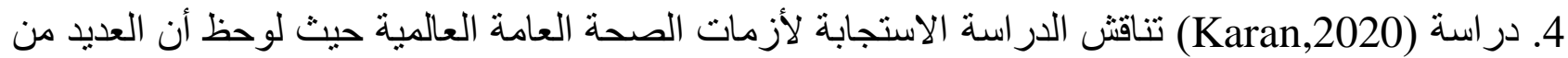

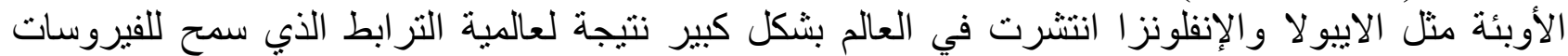

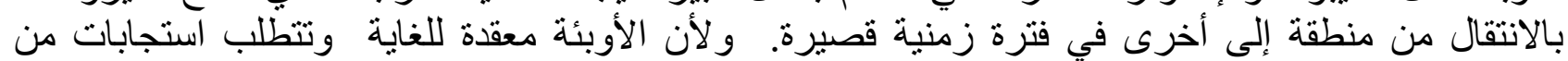

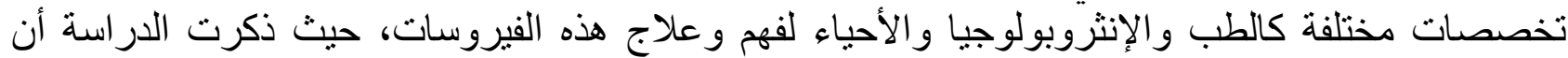

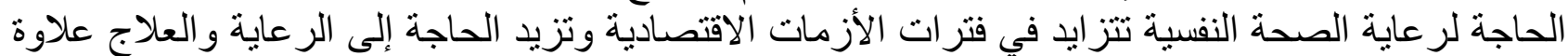

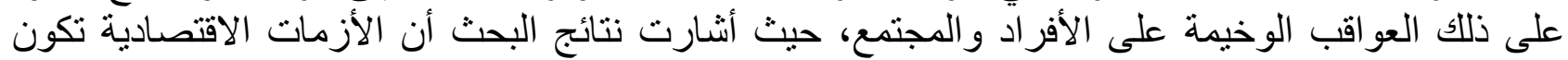

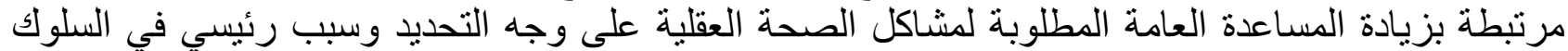

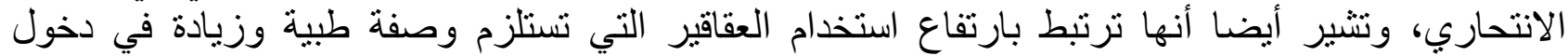

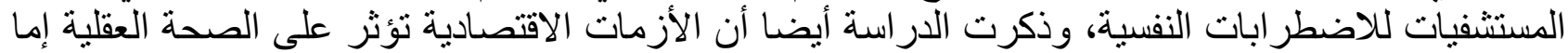

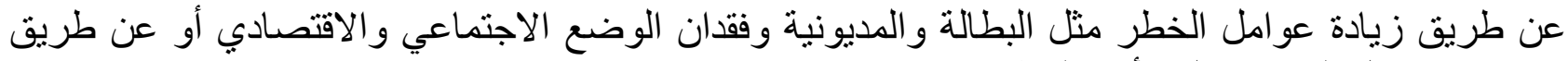

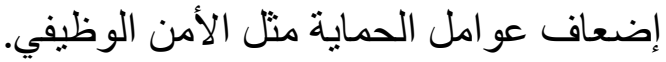




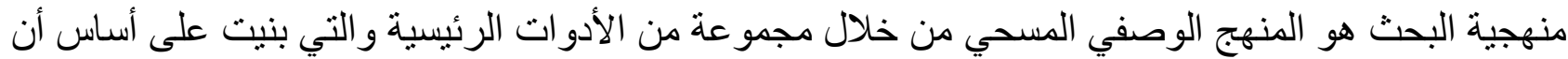

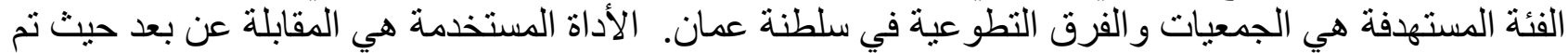
إعداد الأسئلة وعرضها على الفي مجموعة من الخبرات من الجمعيات والفرق التطوعية للتعليق عليها والتعديل عليها، بالإضافة إلى أداة المسح لمحنوى النشر للجمعيات والفرن الفرق التطوعية من خلال مواقعها على الإنترنت

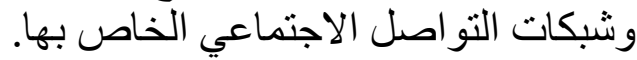
عينة البحث:

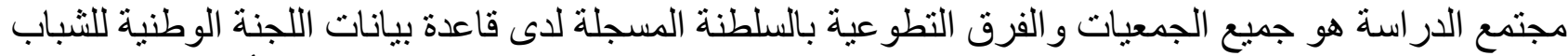
ووزارة التنمية الاجتماعية، وتم اختيار عينة عشوائية من الجمعيات والفرق التطوعية، حيث أن عدد الجمعيات

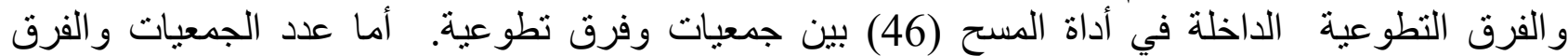

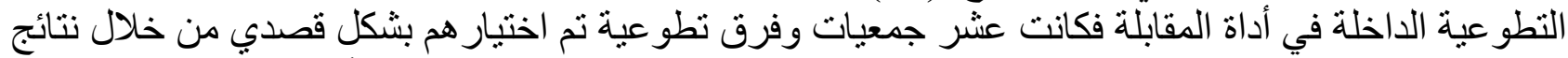

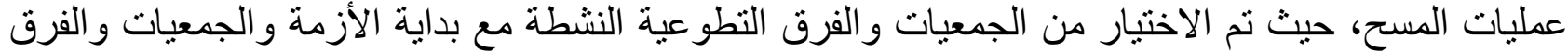
التطوعية غير النشطة بالإضافة إلى التنويع في المجالات بين الخيري والثقافي والاجنماعي والثبابي وذوي الإعاقة.

نتائج الدراسة:

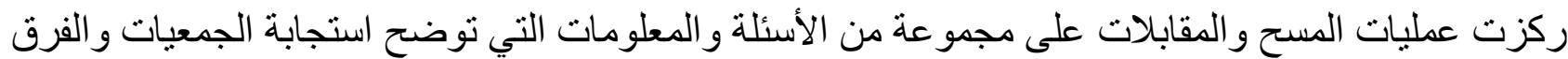

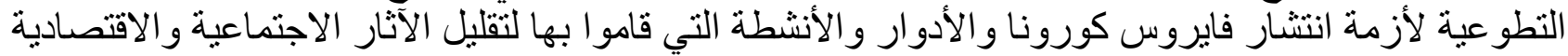

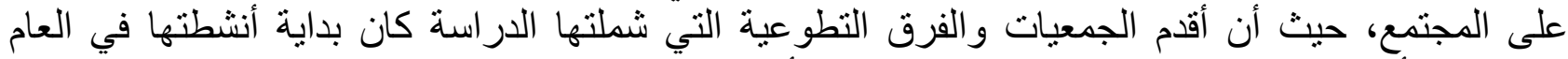
(1993) وأحدثها في العام (2019)، بالإضافة إلى أن الجمعيات والفرق التطوعية التي شملتها المقابلات جميعها قائمة بأعضائها و إدار اتها. أولا: إجابة السؤال الأول: ما دور المتطو عين في التقليل من الآثار الاقتصادية والاجتماعية للأزمات في

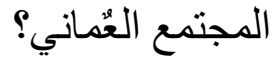

جاءت النتائج كما في جدول (1) التي حصل عليها الباحثون من حيث تحديد الجمعيات و الفرق التطوعية للفئة المستهدفة والتي تعمل عليها ودور هاً في تقديم الخدمات الأساسية لها. الجدول (1): نسب الفئات المستهدفة

\begin{tabular}{|c|c|}
\hline النسبة & الفئة المستهدفة \\
\hline$\% 58$ & كافة فئات المجتمع \\
\hline$\% 15$ & فئة الأسر المعسرة والأيتام \\
\hline$\% 2$ & الأطفال \\
\hline$\% 4$ & الثباب \\
\hline$\% 13$ & ذوي الإعاقة \\
\hline$\% 4$ & كبار السن \\
\hline$\% 2$ & أندية الجاليات \\
\hline$\% 2$ & التبر ع بالدم \\
\hline
\end{tabular}

أظهرت النتائج أن عدد كبير من الجمعيات و الفرق التطوعية العاملة في السلطنة لا نركز على فئة واحدة و إنما

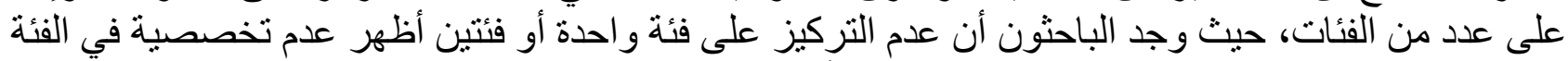

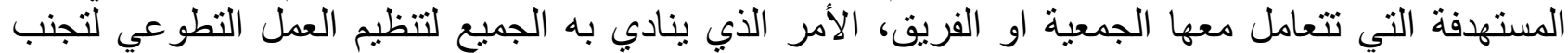

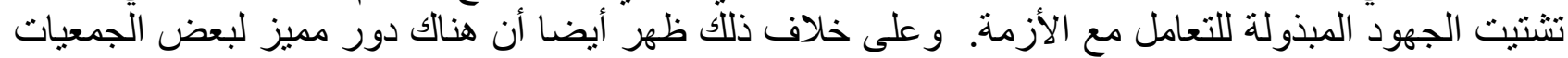

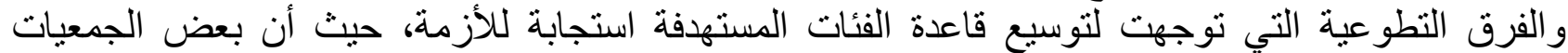

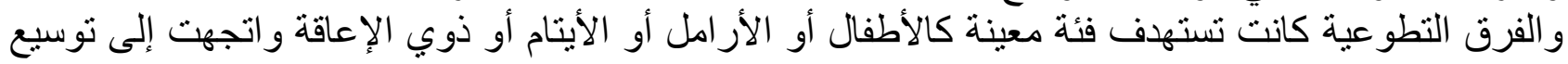


الفئات استجابة للأزمة، بالإضافة إلى أن بعض الجمعيات والفرق التطوعية استمروا في دعم جميع فئات

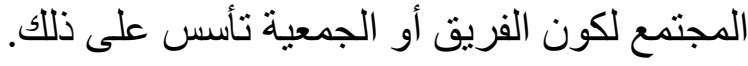

جدول (2) الجمعيات والفرق التطوعية ودور ها في تطوير أنشطتها أو تغيير ها حسب الأزمة

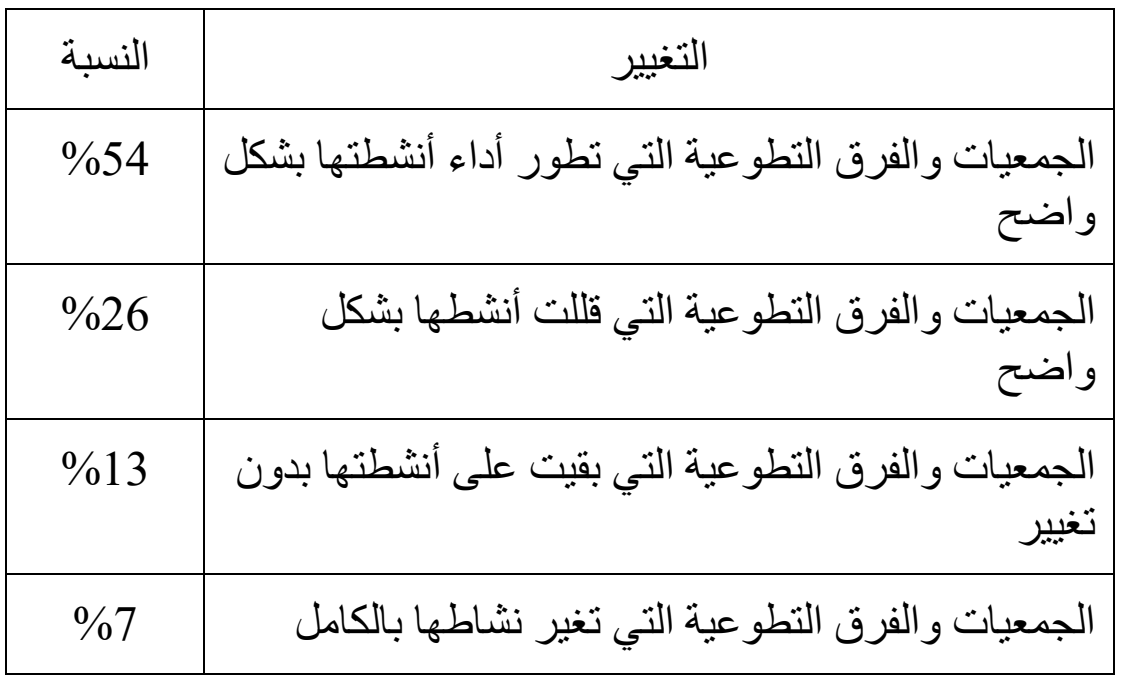

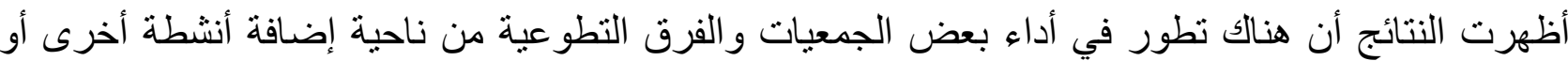
إضافة مجالات أخرى تساعد الجمعية أو الفريق في أداء دوره ومهامه المختلفة استجابة للأزمة، حيث أظهرت النتائج أن هناك إضافة لعنصر التوعية في أغلب الفرق التي شملها المسح إلى إلى جانب الانتقال إلى التطبيقات الإلكترونية والنشر عن بعد لجميع الفعاليات التي يقومون بها، كما توجهت الفرق والجمعيات إلى عقد

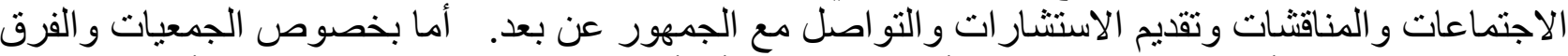

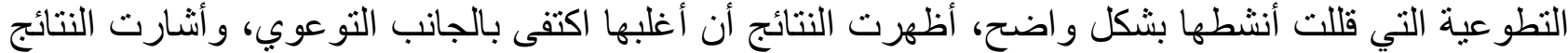

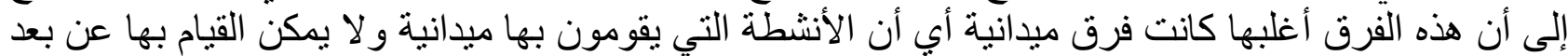

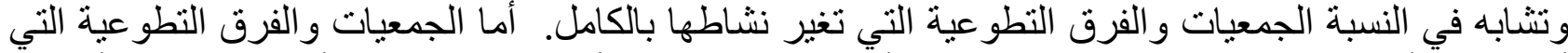

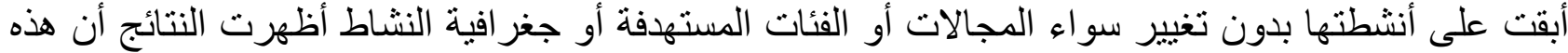

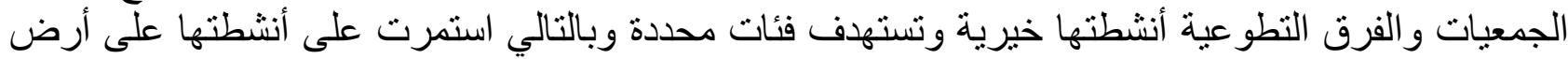
الو اقع مع اتخاذ الاحتياطات الوقائية المناسبة.

أظهرت النتائج أيضا أن هناك بعض الجمعيات والفرق التي توقف النشر في صفحاتهم مع أنها كانت نشيطة قبل

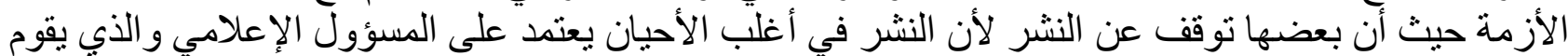

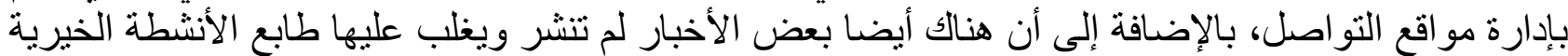

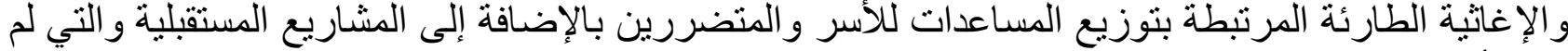

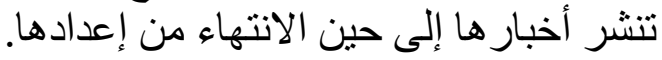
جدول (3) توزع الجمعيات والفرق إلى المجالات المختلفة للتقليل من آثار الأزمة على المجتمع.

\begin{tabular}{|c|c|}
\hline النسبة & التوجه \\
\hline$\% 67$ & الجمعيات و الفرق التطو عية ذات التوجه الاجتماعي \\
\hline$\% 9$ & الجمعيات و الفرق التطوعية ذات التوجه الصحي \\
\hline$\% 11$ & الجمعيات و الفرق التطو عية التي لها توجهات متعددة \\
\hline$\% 11$ & الجمعيات و الفرق التطوعية التي لم يتضح توجهرح بشكل \\
\hline
\end{tabular}




\begin{tabular}{|c|c|}
\hline & و اضح \\
\hline$\% 2$ & خارج الجمعيات والفرق التطوعية التي تعمل في الجانب الإنساني \\
\hline
\end{tabular}

تتوعت أنتطة الجمعيات والفرق التطوعية وتوجهاتها طبقا لأهدافها المتعددة والتي أسست وبنيت عليها وفق

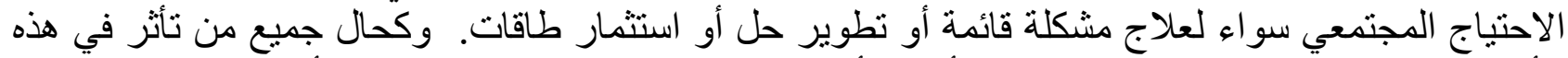

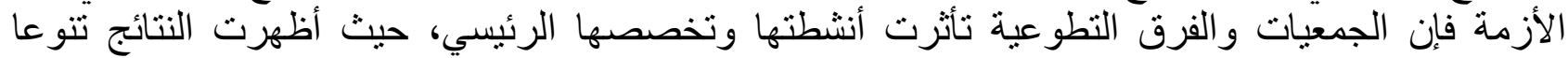

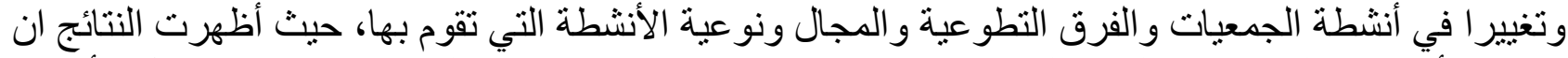

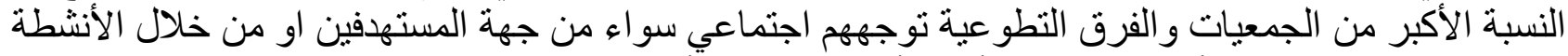

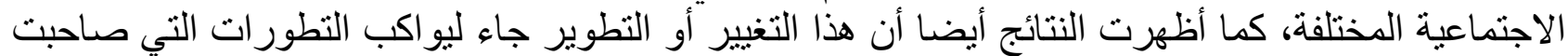

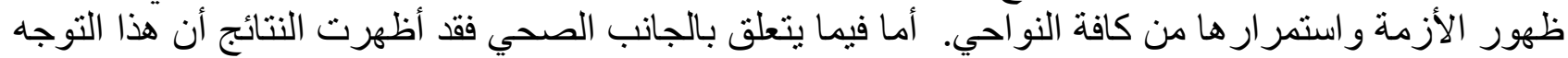

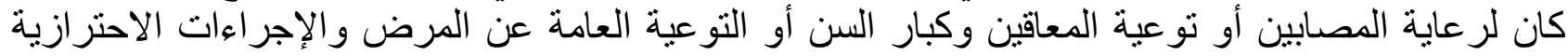

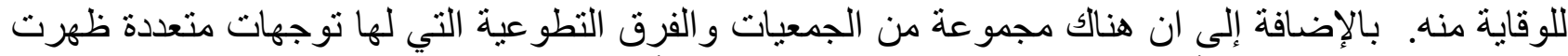
بشكل كبير في مختلف الأنشطة والمبادرات المطروحة وقت الأزمة، ونتشترك هذه الفية النسبة مع نسبة الجمعيات

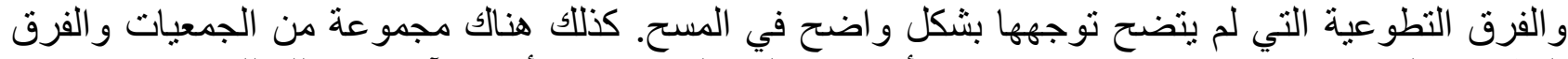

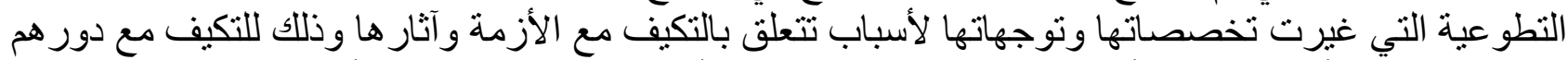

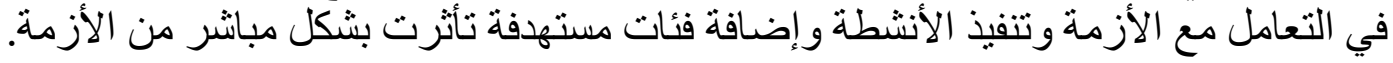
جدول (4) الجمعيات والفرق التطو عية التي استمرت و التي توققت عن أنشطتها

\begin{tabular}{|c|c|}
\hline 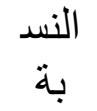 & 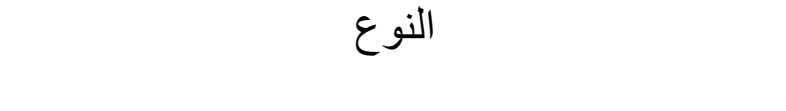 \\
\hline$\% 82$ & أنثطة الجيات و الفرق التطوعية التي استمرت بتقديم \\
\hline$\% 18$ & الجمعيات و الفرق التطو عية التي توقفت \\
\hline
\end{tabular}

أظهرت النتائج أن الجمعيات والفرق التطوعية التي استمرت بتقديم أنشطتها المختلفة كان عن طريق تطوير هذه

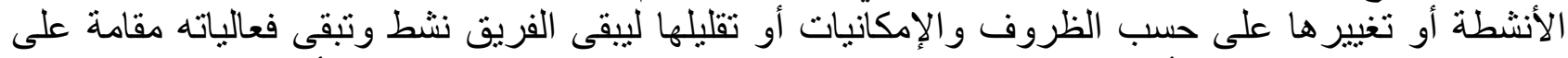

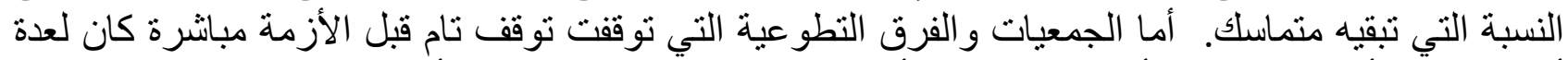

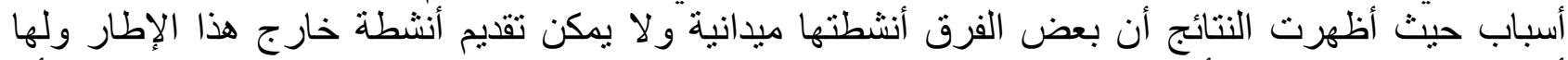

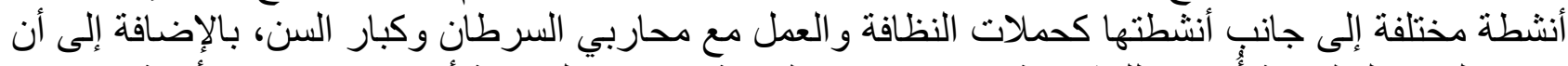

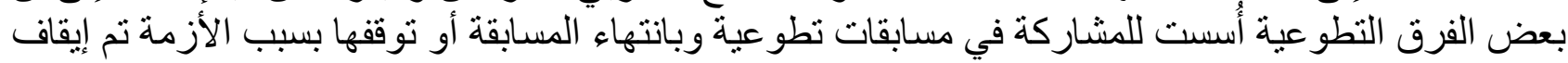
العمل في الفريق.

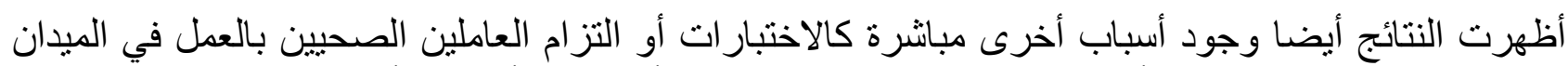

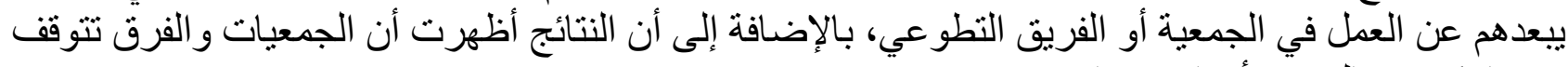
عندما يكون هناك عدة أسباب منها: عدم قدرة الإدارة في التكيف مع الوضع المستجد. عدم وجود تشجيع وحافز للتغيير من البرامج المطروحة. عدم وجود معرفة كافية للتعامل مع الأزمة. الصر اعات الداخلية في الجمعيات الفرق و المشكلات الإدارية. 


$$
\text { الإجر اءات الاحتر ازية. }
$$

ثانيا: إجابة السؤال الثاني: ما دور المؤسسات الحكومية والخاصة تجاه الجمعيات والفرق التطوعية فيما يتعلق بالأزمات؟ جاءت النتائج على الشكل التالي: جدول (5) الجمعيات و الفرق التطوعية التي تعاونت مع الجهات الحكومية و القطاع الخاص و الفرق التطوعية

\begin{tabular}{|c|c|}
\hline النسبة & النوع - \\
\hline$\% 61$ & تعاونت مع مختلف الجهات \\
\hline$\% 39$ & لم يكن بينها وبين أي جهة من الجهات أي \\
\hline
\end{tabular}
و الجمعيات

أظهرت النتائج أن هناك تعاون من الجمعيات والفرق التطوعية مع مختلف الجهات الحكومية و اللجنة الرئيسية

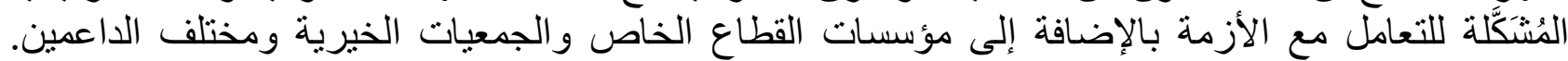

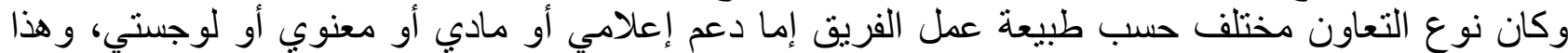

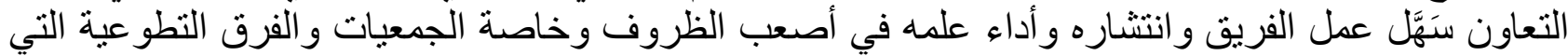

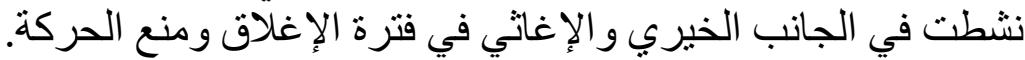
أظهرت النتائج أيضا أن الجمعيات و الفرق التطوعية التي لم يكن بينها وبين أي جهة من الجهات تعاون خلال

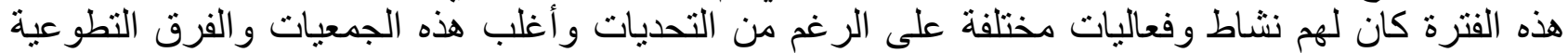
أنشطتها ثقافية وتوعوية وتمت عن بعد باستخدام مختلف التطبيقات و البر امج على الإنترنت.

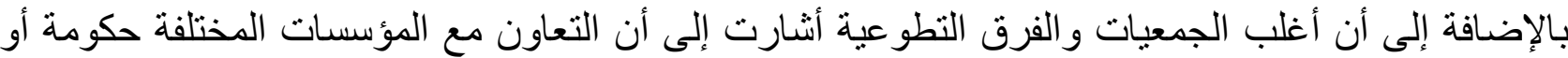

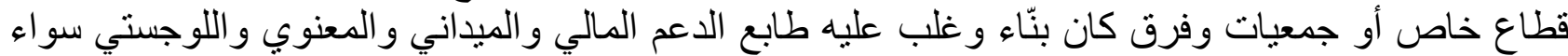

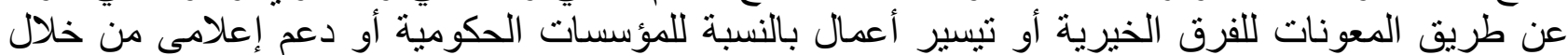

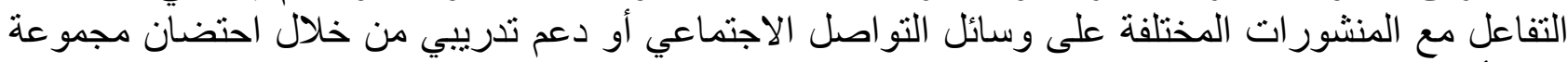
من الأعضاء وتدريبهم. ثالثا: إجابة السؤال الثالث: ما الاستعدادات التي يجب أن تكون عليها الجمعيات والفرق التطوعية للتعامل مع الازمات؟ هناك مجمو عة من الاستعدادات يجب أن تركز عليها الجمعيات و الفرق التطوعية لكي تدير الأزمة بشكل فاعل و تقوم بدور ها المنوط بها للتقليل من آثار ها على المجتمع حيث جاءت الت النتائج على الثكل التالي:

\begin{tabular}{|c|c|}
\hline 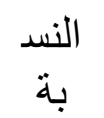 & النوع \\
\hline$\% 83$ & وإدارتهايات والفرق التطوعية التي لم تخضع للتدريب على الأزمات \\
\hline
\end{tabular}
جدول (6) الجمعيات و الفرق التطو عية التي خضعت للتدريب على إدارة الأزمات 


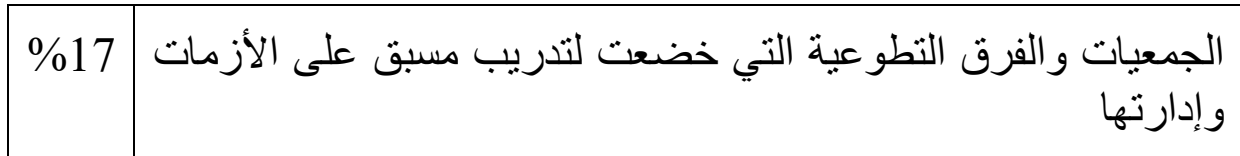

أظهرت النتائج أن النسبة الأكبر من الجمعيات والفرق التطوعية لم تخضع للتدريب على الأزمات و إدارتها،

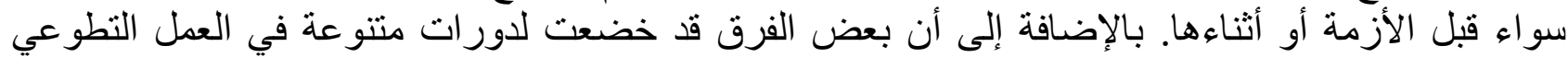

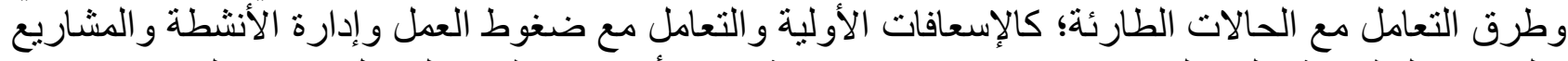

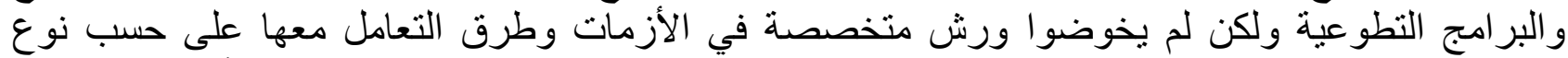

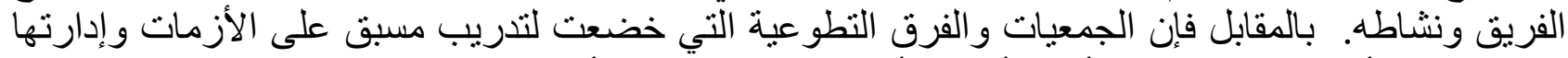

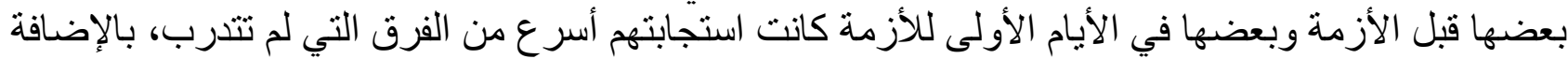

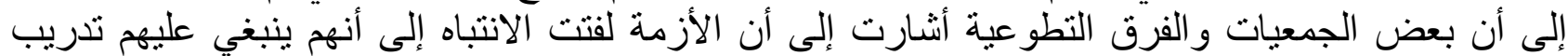

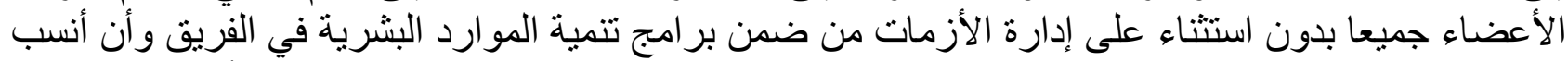

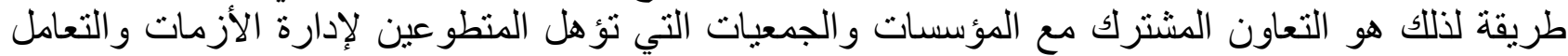

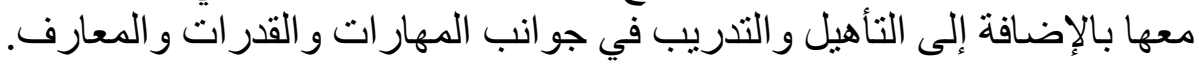
الجدول (7): المنطقة الجغر افية التي تتشط فيها الجمعيات و الفرق التطو عية

\begin{tabular}{|c|c|}
\hline النسبة & النوع \\
\hline$\% 67$ & الجمعيات و الفرق التطو عية التي تنشط في مناطق \\
\hline$\% 33$ & تنشط في كافة مناطق السلطنة \\
\hline
\end{tabular}

أظهرت النتائج أن الجمعيات والفرق التطوعية التي يكون نشاطها محدد في ولاية أو محافظة يكون نشاطها

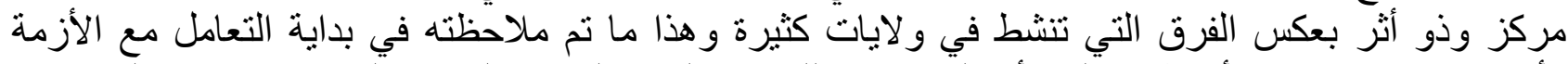

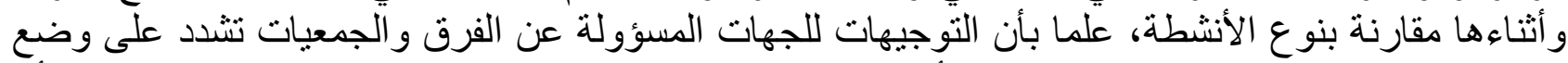

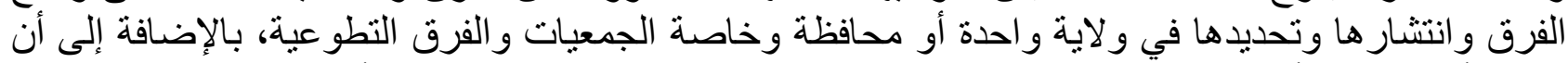

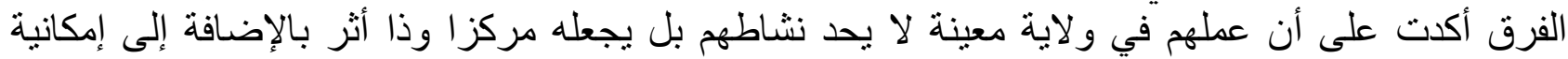

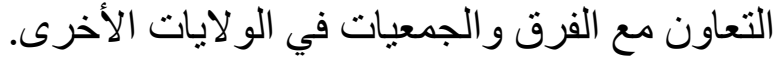

الجدول (8) جدولة فتر ات الاستجابة للأزمة من قبل الجمعيات والفرق التطوعية

\begin{tabular}{|c|c|c|}
\hline نوعية الاستجابة & الاستجابات لعينة & القترة الزمنية \\
\hline صحية استجات توعوية ونصائح & 4 استجابات & فبر اير 1 يناير 2020 2020م إلى 24 \\
\hline استجابات تو عية صحية وتنبيهات & 6 استجابات & من 25 فبر اير 2020 إلى 11 مارس \\
\hline واقتصابات اجتماعية وخيرية & 33 استجابة & من 12 مارس 2020م إلى 2 أبريل \\
\hline
\end{tabular}




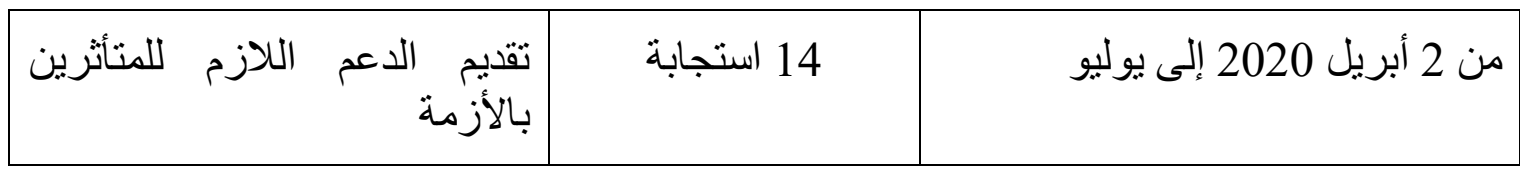

أظهرت النتائج أن أول الاستجابات كانت توعوية ونصائح صحية و أغلبها لا دخل لها بشكل مباشر بالأزمة و إنما

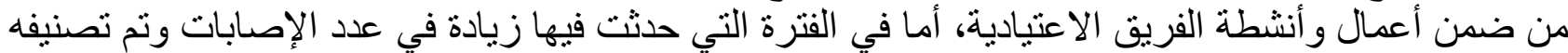
كجائحة عالمية من قبل منظمة الصحة العالمية زاد عدد الاستجابات وجميعها استجابات توعية صحية وانية وتنبيهات

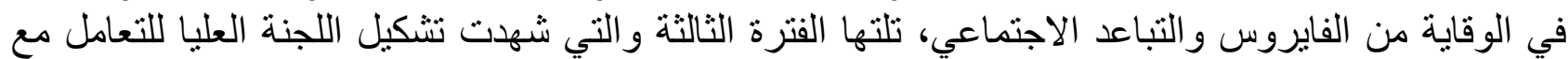

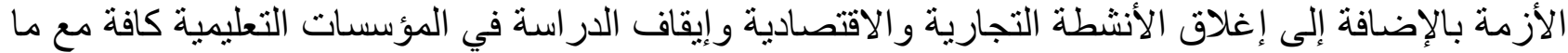

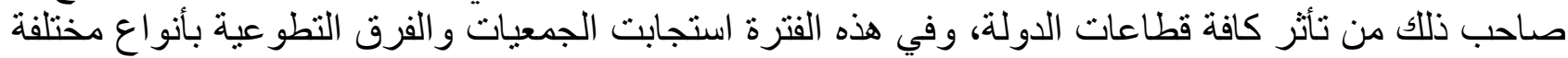

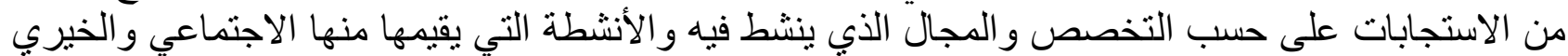

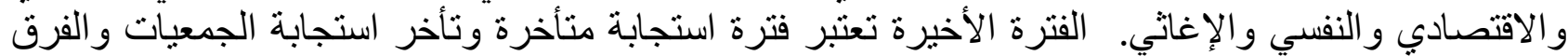

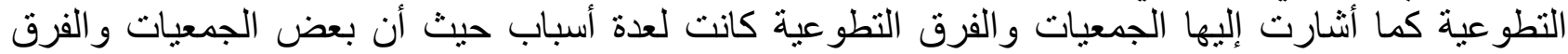

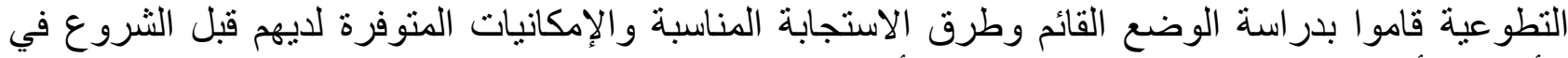
الأنشطة و أغلب هذه الدر اسات ركزت على المتأثرين من الناحية الاقتصادية وتقديم الدعم اللازية الإنم لهح.

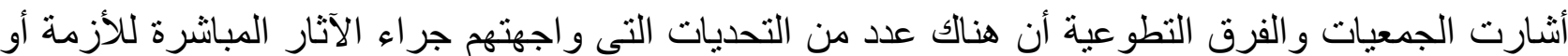
من الآثار الجانبية التي نتجت من تأثر المجتمع خلال فترات مختلفة مما شجع الاستعداد لها بابتكار وسائل

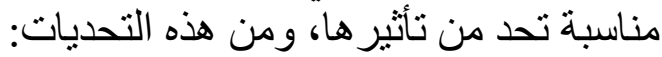
التو اصل مع الفئات المستهدفة بشكل مباشر وخاصة في الجانب الخيري كون بعض الأسر كان اعتمادها الأكبر

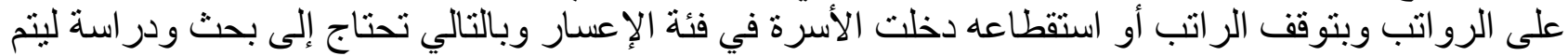

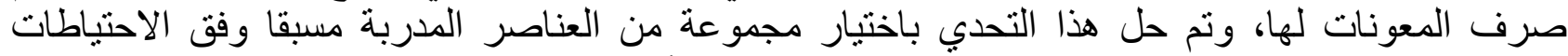
الاحترازية لزيارة الفئات المستهدفة، بالإضافة إلى ابتكار أدوات إلكترونية تساعد في جمع المعلومات الضرورية.

الدعم وصعوبة الاستلام المباشر من الداعمين وتم حل هذا التحدي بالاستفادة من التطبيقات الإلكترونية للدفع عن طريق البنوك المحلية بالسلطنة.

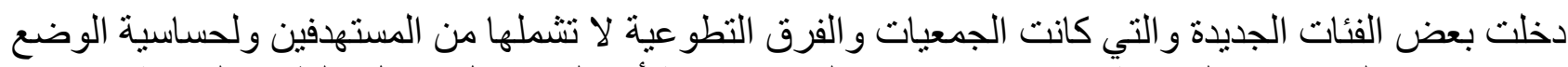

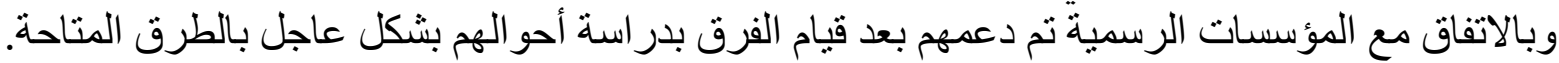
التحدي الأكبر كان الانتقال إلى الجانب التقني و الذي شكل تحديا خاصة لذوي الإعاقة وكبار السن وكان و اضحا

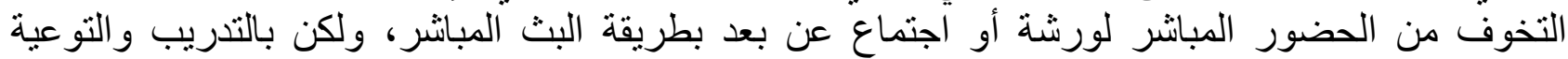

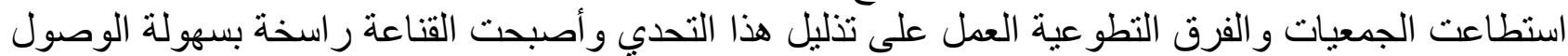
إلى مختلف الأعضاء في الفريق. بعض الفرق والجمعيات تأثر أعضاءها من الجانب النفسي ففضل بعضهم عدم العمل مع الفريق إلى أن تزول

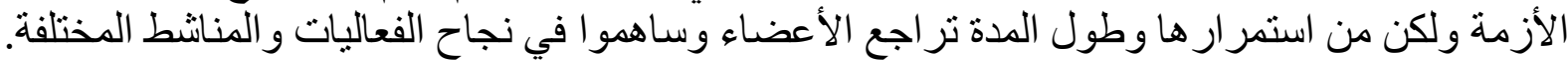

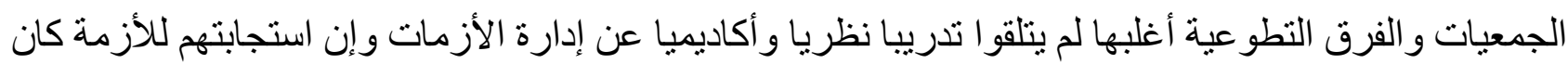

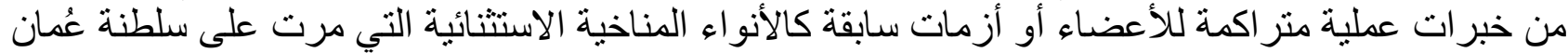

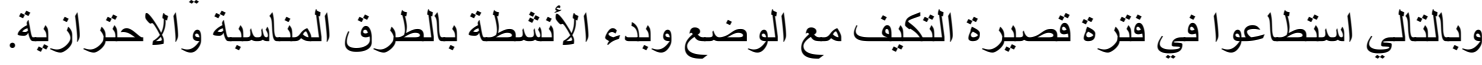
مجمو عة من الجمعيات والفرق التطو عية لم تتعامل مع أزمة مسبقا وأزمة كورونا هي الأزمة الأولى لهم سواء

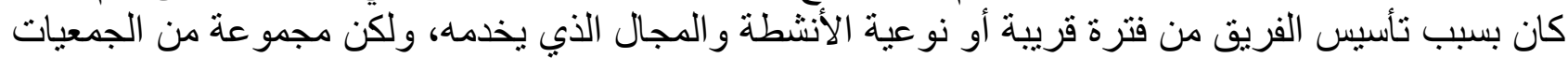

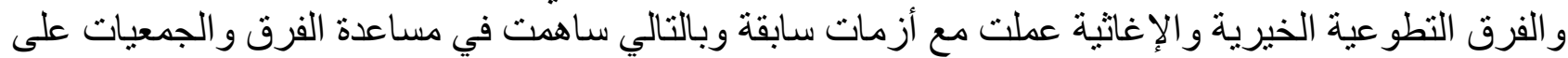
الاستعداد لتقليل الآثار. 
استجابة المجتمع لأنشطة الجمعية أو الفريق كانت ضعيفة في بداية تحويل الأنشطة إلى أنشطة عن بعد ولكن ازداد العدد بشكل و اضح بعد فترة وكان هنالك حضور قوي في بعض الأنشطة المستحدثة والتي تقدم عن بعد،

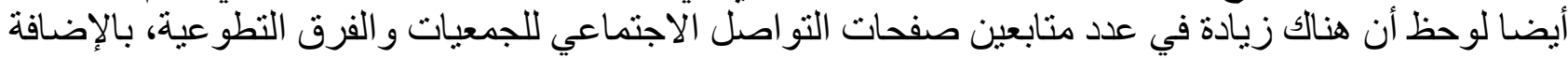
إلى زيادة زيار ات المو اقع الإلكترونية والاستفادة من الخدمات التي توفر ها مختلف الجمعيات و الفرق التطوعية في السلطنة.

أشـارت أيضا الجمعيات والفرق التطوعية إلى أن الاستفادة من الأزمة كان كبيرا على الرغم من الأضرار الكبيرة على الفرد و المجتمع و الدولة وخاصة من الجانب الاقتصادي ومن هذه الفئه الفو الائد:

كثفت الجائحة عن مجمو عة من مو اهب أعضاء الجمعيات و الفرق التطو عية كانت مخفية و لا يعرف عنها أحد.

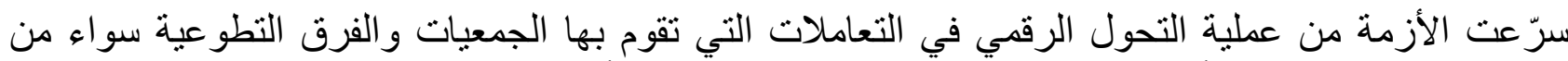
جوانب التحويلات المالية أو من جو انبة نشر الوعي الرقمي ومحو الأمية الرقمية. توسيع دائرة المستفيدين من البرامج و الدورات المقدمة، حيث وصلت الأرقام للمستفيدين من الورش و البرامج التي تقدم عن بعد إلى المئات ومن دول مختلفئة

ساعدت الجمعيات و الفرق التطو عية على قياس استعدادها ومدى قدرتها للتعامل مع الأزمات في المستقبل.

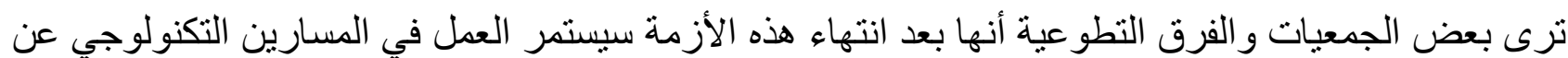

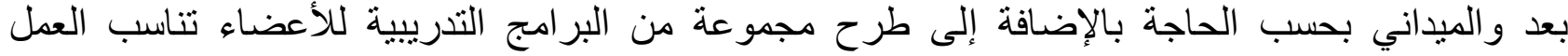
المستقبلي في ظل التطور ات المسيدمرة.

التوصيات:

أظهرت النتائج تنو عا كبير ا في الجمعيات و الفرق التطو عية و أدوار ها في التقليل من الأزمة التي سببتها الجائحة، و هنا نضع بعض التوصيات التي نرى أنه لو تم تطبيقيها في هذه الأزمة لسهل على الجمعيات و الفرق التطوعية

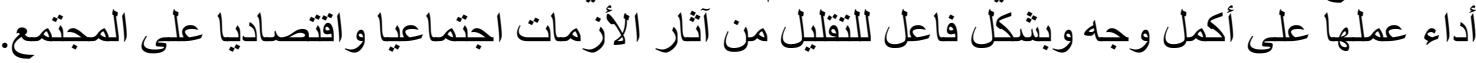

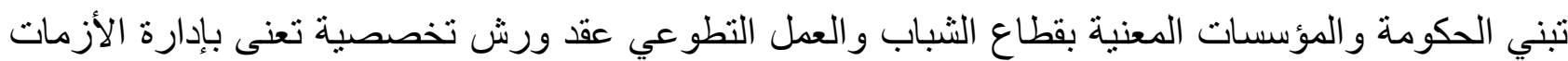
ويتم تعميمها على جميع الجمعيات و الفرق التطوعية في كافة مناطق السلطنة، ويقترح الباحثُون مجموعة من العناوين المهمة والتي يجب أن تغطيها الورش الموجهة للجمعيات و الفرق التطو عية، ومنها:

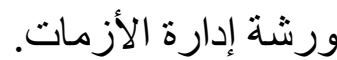
ورشة ثقافة العمل التطوعي. ورشة إدارة وتتفيذ المشاريع التطو عية. ورشة استر اتيجيات إدارة الفرق التطو عية. ورشة تحليل التحديات المجتمعية و الإحاطة بالقضايا الاجتماعية. ورشة الإسعافات الأولية. ورشة الإدارة المالية. ورشة الإعلام الاجتماعي للجمعيات و الفرق التطو عية. ورشة إدارة المواقع ووسائل التو اصل الاجتماعي. ورشة التو اصل الرقمي. تشجيع عمليات البحث العلمي في الجمعيات والفرق التطوعية لابتكار أنسب الطرق لتذليل العقبات و التحديات، ويقترح الباحثون مجمو عة من العناوين للبحث العلمي، منها: 
أثر تدريب الجمعيات والفرق التطوعية على إدارة الأزمات في إدارتهم للأزمات المختلفة. فاعلية برنامج تدريب ميداني للمتطو عين لرفع مستو اهم المهاري و المعرفي. دور الجمعيات و الفرق التطوعية في تقليل المشاكل المجتمعية لذوي الإعاقة. التخصص في الفئات المستهدفة في العمل التطوعي ودوره في تمكين الفرق التطوعية. أثر المسابقات التطو عية في إخر اج فرق تطو عية تعمل بطرق ممنهجة. توجيه جزء من الدعم المقدم من الجهات الداعمة إلى التنمية المستدامة في الجمعيات والفرق. فتح قنو ات حوار بين الجمعيات و الفرق التطو عية و التشبيك بينها. التوعية بأهمية إنتاج مقاطع توعوية ومنشور ات تر اعي ذوي الإعاقات المختلفة. عدم إغلاق التطبيقات التي تبث عن بعد بشكل منز امن عن طريق الإنترنت و التي كانت مغلقة سابقا من هيئة تتظيم الاتصالات. الاستفادة من القدر ات و الإمكانيات التي تمتلكها الجمعيات والفرق التطو عية واتو العمل على تطوير ها ودعمها لكي

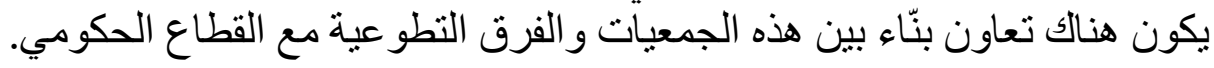
تشكيل كيان مركزي يتم تفعيله في الأزمات يعنى بدور الجمعيات و الفرق التطوعية في الأزمات ويتم تفعيله في لهي بداية الأزمات. تبني استر اتيجية متكاملة من الجمعيات و الفرق التطو عية للتدريب وتكون بشكر مستمر. بناء موقع إلكتروني به قاعدة بيانات جميع الجمعيات والفرق التطوعية العاملة في السلطنة ليسهل الرجوع إليها

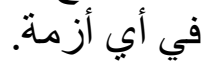
تفعيل دور الاختصاصين النفسيين في التقليل من آثار هذه الأزمة و غير ها من الأزمات على الفرد و المجتمع. ابتكار بر امج تدريبية تناسب التعامل النفسي والاقتصادي والاجتماعي مع الأزمة. توجيه الجمعيات والفرق التطوعية على أهمية النشر للأنشطة والبرامج التي يقومون بها والتي يمكن إطلاع

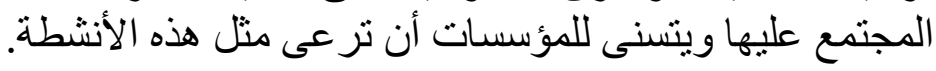
ضرورة توجيه الجمعيات والفرق التطوعية إلى التخصصية في التوجهات والأنشطة و الفئة المستهدفة.

\section{قائمة المراجع العربية:} التمامي، علي. (2018). استخدام تعديل السلوك في خدمة الجماعة وتعديل اتجاهات الثباب نحو المشاركة في

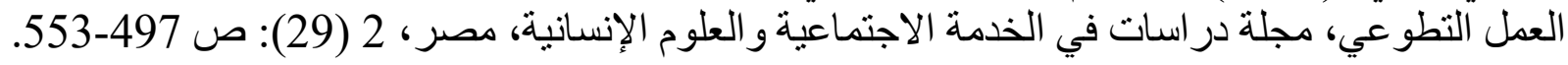
التهامي، حسين. (2008)، المدخل إلى در اسة السلوك الإنساني، الجيزة: الدار العالمية للنشر و التوزيع. الخضيري، محسن. (2003). إدارة الأزمات منهج اقتصادي إداري لحل الأزمات على مستوى الاقتصاد القومي و الوحدة الاقتصادية، ط2، القاهرة: مكتبة مدبولي. الرازي، ححمد أبي بكر. (1999). قاموس مختار الصحاح، ط5، بيروت: المكتبة العصرية

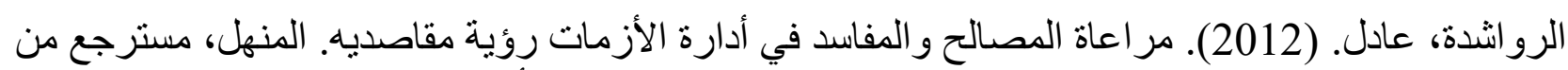

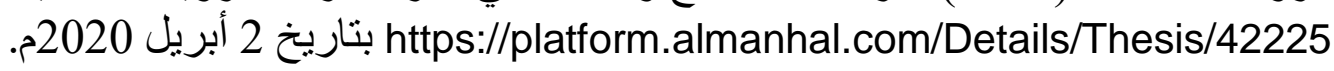
السبعاوي، يونس ويوسف، إيهاب وعوض، عبد الستار. (2018). المعرفة الاستر اتيجية ودور ها في إدارة مر احل الأزمات، مجلة كلية الإسراء الجامعة. 2(1). 
الفر ا، مر ام تيسير. (2020). تأثير ات أزمة فيروس كورونا على أداء الاقتصاد العالمي و على أداء مؤسسات

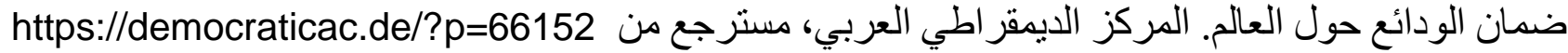
بتاريخ 26 مايو 2020م.

اللامي، غسان والعيساوي، خالد. (2015). إدارة الأزمات الأسس والتطبيقات. جامعة الفلوجة، مسترجع من http://ufds.uofallujah.edu.iq/dspace/handle/123456789/925?mode=full 2020

الأونروا. (2020). فيروس كورونا المستجد (COVID-19). دليل توعوي صحي شامل، مسترجع من 20ناريخ 20 مايو 2020م. بورونا

اليو انسة، ابرار. (2020، مايو 9). تأثثر فيروس كورونا على الاقتصاد العالمي. مجلة الوطن، مسترجع من https://alwatannews.net/article/876652/Business بيندير، ليسا. (2020). رسائل وأنشطة رئيسيه للوقاية من مرض (كوفيد-19) والسيطرة عليه في المدارس.

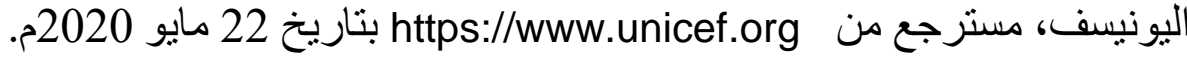
جبر، ححم. (1998). المعلومات واهميتها في إدارة الأزمات، تونس: المجلة العربية للمعلومات. حنانيا، رائد خليل. (2010). دور المتطوعين الأجانب في تطوير العمل المؤسسي في المؤسسات الثبابية في

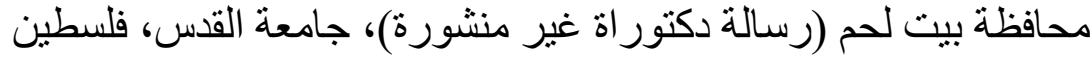

شامخ، دلال. (2020)."المعالجة الإعلامية للكوارث الطبيعية بإذاعة تبسة الجهوية: أنموذج فيضانات سبتمبر

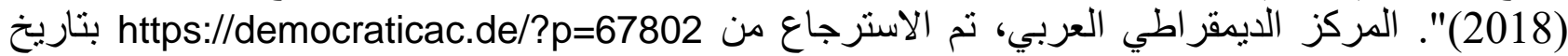
10 مايو 2020م. عباس، منال. (2019). العمل التطوعي بين الواقع و المأمول، الإسكندرية: دار المعرفة الجامعية.

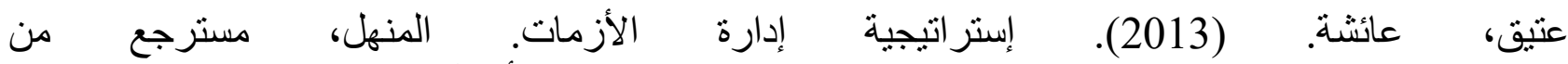
2. بتاريخ 2 أبريل 2020://platform.almanhal.com/Reader/Article/119686، كامل، عبد الوهاب. (2005). سيكولوجية إدارة الأزمات المدرسية، عمان: دار الفكر للطباعة و النشر و التوزيع. منظمة الصحة العالمية.. (2020). اعتبار ات الصحة النفسية والدعم النفسي والاجتماعي أثناء فاثية (كوفيد19). المكتب الإقليمي لثرق المتوسط، مسترجع من /https:/www.who.int/en بناريخ 20 مايو 2020م. هلال، ححمد عبد الغني. (2004). مهار ات إدارة الأزمات، ط4، القاهرة: مركز تطوير الأداء والتنمية. وزارة الصحة. (2020). مرض فيروس كورونا (كوفيد-19) بيانات وتحديثات. سلطنة عمان، مسترجع من 2. بتاريخ 26 مايو 2020م.

\section{ARABIC REFERENCES IN ROMAN ALPHABETS}

Altimami, Eali. (2018). Aistikhdam Taedil Alsuluk Fi Khidmat Aljamaeat Wataedil Aitijahat Alshabab Nahw Almusharakat $\mathrm{Fi}$ Aleamal Altatawueii, Majalat Dirasat Fi Alkhidmat Alaijtimaeiat Waleulum Al'iinsaniati, Musr, 2 (29): S 497-553.

Altahami, Husayn. (2008), Almudkhil 'lilaa Dirasat Alsuluk Al'iinsanii, Aljyzt: Aldaar Alealamiat Lilnashr Waltawzie. Alkhadiri,

Mahsun. (2003). 'lidarat Al'azamat Manhaj Aiqtisadiun 'lidariun Lihali Al'azamat Ealaa Mustawaa Alaiqtisad Alqawmii Walwahdat Alaiqtisadiati, T2, Alqahrt: Maktabat Madbuliun.

Alrrazi, Muhamad 'Abi Bkr. (1999). Qamus Mukhtar Alsahahi, T5, Byrwt: Almaktabat Aleasria

Alruwashdt, Eadil. (2012). Muraeat Almasalih Walmufasid Fi 'Adarat Al'azamat Ruyat Muqasidyh. Almunahala,

Alfaraa, Maram Tisyr. (2020). Tathirat 'Azmat Fayrus Kwrwna Ealaa 'Ada' Alaiqtisad Alealamii Waealaa 'Ada' 
Muasasat Daman Alwadayie Hawl Alealam. Almarkaz Aldiymuqratii Alearabii, Mustarjae Min Https://Democraticac.De/?P=66152 Bitarikh 26 Mayu 2020m.

Allaami, Ghassan Waleaysawi, Khalud. (2015). 'lidarat Al'azamat Al'usus Waltatbiqat. Jamieat Alfalwajat, Mustarjae Mina Http://Ufds.Uofallujah.Edu.Iq/Dspace/Handle/123456789/925?Mode=Full Bitarikh 17 'Aghustus 2020m. Al'uwnurwa. (2020).

Fayrus Kwrwna Almustajd (Covid-19). Dalil Tawewi Sahi Shaml, Mustarjae Min Https:/Www.Unrwa.Org Bitarikh 20 Mayu 2020m. Alywansat, Abrar. (2020, Mayu 9). Tathir Fayrus Kwrwna Ealaa Alaiqtisad Alealami. Majalat Alwatn, Mustarjae Min Https://Alwatannews.Net/Article/876652/Business Bitarikh 20 'Aghustus 2020m.

Bindir, Laysa. (2020). Rasayil Wa'anshitatan Rayiysiah Lilwiqayat Min Marad (Kwafid-19) Walsaytarat Ealayh Fi Almadaris. Alyunisf, Mustarjae Min Https:/Www.Unicef.Org Bitarikh 22 Mayu 2020m.

Jabar, Mahmud. (1998). Almaelumat Wahamiataha Fi 'lidarat Al'uzmati, Tunis: Almajalat Alearabiat Lilmaelumati.

Hnania, Rayid Khalil. (2010). Dawr Almutatawiein Al'ajanib Fi Tatwir Aleamal Almuasisii Fi Almuasasat Alshababiat Fi Muhafazat Bayt Lahm (Rsalt Dukturat Ghyr Mnshwr), Jamieat Alqudsa, Filastin

Shamikh, Dalal. (2020)."Almuealajat Al'iielamiat Lilkawarith Altabieiat Bi'iidhaeat Tibsat Aljahwiati: 'Anmudhaj Fayadanat Sibtambar (2018)". Almarkaz Aldiymuqratia Alearabii, Tama Alaistirjae Min Https://Democraticac.De/?P=67802 Bitarikh 10 Mayu 2020m.

Eabaas, Manal. (2019). Aleamal Altatawei Bayn Alwaqie Walmamul, Al'iiskandariat: Dar Almaerifat Aljamieiat.

Eatiq, Eayishat. (2013). 'listratijiat 'lidarat Al'azmat. Almunhal, Mustarjae Min Https://Platform.Almanhal.Com/Reader/Article/119686 Bitarikh 2 'Abril 2020m.

Kamil, Eabd Alwhab. (2005). Sayakulujiat 'lidarat Al'azamat Almadrsiati, Eamana: Dar Alfikr Liltabaeat Walnashr Waltawzie.

Munazamat Alsihat Alealamiat. (2020). Aietibarat Alsihat Alnafsiat Waldem Alnafsia Walaijtimaeii 'Athna' Fashia (Kwafida-19). Almaktab Al'iiqlimia Lisharq Almutawasiti, Mustarjae Min Https://Www.Who.Int/En/ Bitarikh 20 Mayu 2020m.

Hilala, Muhamad Eabd Alghani. (2004). Maharat 'lidarat Al'uzmati, T4, Alqahrt: Markaz Tatwir Al'ada' Waltanmiati.

Wizarat Alsihat. (2020). Marad Fayrus Kwrwna (Kwafyd-19) Bayanat Watahdithat. Saltanat Eamaan, Mustarjae Min Https://Www.Moh.Gov.Om/Ar/-59 Bitarikh 26 Mayu 2020m.

\section{REFERENCES:}

Poole, D. N., Escudero, D. J., Gostin, L. O., Leblang, D., \& Talbot, E. A. (2020). Responding to the COVID19 pandemic in complex humanitarian crises. International Journal for Equity in Health, 19(1), 1-2.

Karan, A. (2020). Responding to global public health crises. American Medical Association Journal of Ethics, 22(1): E3-4. DOI: 10.1001/amajethics.2020.3

Singh, Jaspreet. (2020). COVID-19 and Its Impact on Society, Electronic Research Journal of Social Sciences and Humanities, Jan - Mar 2020, (PhD Research Scholar), Central University of Jammu, India, M.Sc. Electronics, University of Jammu, India

Xie, B., He, D., Mercer, T., Wang, Y., Wu, D., Fleischmann, K. R., ...Leem, M. K. (2020). Global health crises are also information crises: A call to action. Association for Information Science and Technology, 1 5. DOI: $10.1002 /$ asi.24357 